\title{
Application of Soft Computing and Non-parametric Approach in the Evaluation of West Africa Economic Growth
}

\author{
Shaibu Suleman P. \\ Department of Computer \\ School of Information and \\ Communication Technology \\ Sciences, Auchi Polytechnic, \\ P.M.B 13, Auchi, Nigeria
}

\author{
Isah Mohammed M. \\ National Institute for Educational \\ Planning and Administration, \\ (NIEPA_NIGERIA), P.M.B 562, \\ Ondo, Ondo-city, Nigeria
}

\author{
Akhuewu Divine Emoata \\ Department of Computer \\ School of Information and \\ Communication Technology \\ Sciences, Auchi Polytechnic, \\ P.M.B 13, Auchi, Nigeria
}

\begin{abstract}
This research work attempts to measure economic growth by utilizing financial development of ECOWAS member nations. The financial sector drives the economy of any nation and they play significant role towards development of any economy because both private sectors and the government assess capital for various projects from them. Several factors influence the performance of this sector especially information security, government monetary policies and intermediate market trends. Some of these factors or determinant assumes values represented in linguistic form, ratio and missing values. Applying Genetic Algorithm (GA) as optimum search methodology will help identify best subset of determinants that can be used to measure economic growth, fuzzy logic address the uncertainty and imprecision owing to the occurrence of missing values, ratios and linguistic value and non-parametric methodology, i.e. Data Envelopment Analysis (DEA) will compute the efficiency of each member nation between 1990 to 2015. The resulting model GAFDEA is a dynamic hybrid (Input- oriented) efficiency model that shows the efficiency of a country. Among the ECOWAS countries, before 2005 only Liberia and after 2009, Liberia, Nigeria and Sierra Leone seems to be efficient in both models which seem to be good or efficient benchmark countries in the area of financial development respectively. On the other hand, Gambia and Togo dominate the inefficient range. The empirical results also suggest that, in general, ECOWAS nations are very perfectly efficient and partially efficient in financial development which in turn influence the economic growth of these countries
\end{abstract}

\section{Keywords}

Genetic Algorithm (GA), Economic growth, Gross Domestic Product(GDP), Gross National Product(GNP), Foreign Direct Investment (FDI), Information Security, Monetary Policies, Balance of Payment.

\section{INTRODUCTION}

Economic growth (EG) is a measure of the total well-being of the citizens in a country. EG is a complex macroeconomic phenomenon, which is why its sources and the extent of influence, as well as its contribution to national growth, have yet not been clearly understood, adequately conceptualized and fully explained. It could be partly attributed to the lack of a generalized or unifying theory, and the simplistic and very abstract way conventional economics approach these issues [15]. Therefore, efforts to make progress in clarifying these questions, which implies exploring and explaining development gaps between countries, remain an important theoretical and empirical task [73]. The determinants of EG are Investment; Human Capital; Innovation and Research and development(R\&D); Economic Policies and Macroeconomic Conditions; Openness to trade; Institutional factors; Political factors; Socio-cultural factors; Geographical factors; and Demographic factors [15]. Globally, accessing a nation's EGs is anchored on any of Gross Domestic Product (GDP), Gross National Product (GNP) and Balance of Payments (BOP). GDP is the market value of all the products and services that are produces by the people and property of a given country, for the period of one year[5]. GNP is the total measure of the flow of goods and services at market value resulting from current production during a year in a country, including net income from abroad [73]. BOP is overall record of accounts of all the transactions between residents or people of a country and rest of the world [17]. Both GNP and GDP are efficient but GDP is more favoured and used in evaluation. In other words, GDP is more concerned towards, where the production occurred and is less concerned with, who produced it [78][2].

GDP, BOP and GNP are juxtaposed economic determinants when evaluating EGs of a nation. Selecting economic indicators for evaluating these determinants varies among researchers in this domain. Most researchers have employ evaluation tools such as regression analysis in measuring them separately without considering the interrelatedness or correlation among these independent economic indicator. Also, in any system of government, monetary policies and fluctuating market prices possess various degree of uncertainty or risk on investment which has spontaneous effects on all the independent factors. Globalization effects have revolutionized the financial system which have also introduce uncertainty or imprecision among these determinant.

\section{ECONOMIC GROWTH AND MEASUREMENT MODELS}

\subsection{Economic Growth Associated Factors}

\subsubsection{Foreign Direct Investment FDI}

Foreign Direct Investment (FDI) is generally considered as a factor which enhances economic growth, as well as the solution to the economic problems of developing countries. That deals with causality link between FDI, GDP, Exports and Import. He founded bidirectional causality between FDI and GDP, FDI and Export, GDP and Export, and Imports and Exports. Awan [17] examined that overall impact of FDI 
inflows into the economy of Pakistan, by using annual time series data for the period of 1971-2008 and the results indicated that Gross Fixed Capital Formation (GFCF), Degree of Trade Openness (TO) and Inflation rate (INF) are statistically significant with positive signs. Ahmed and Mortaza [6] investigated the relationship between inflation and economic growth in the context of Bangladesh and the empirical evidence demonstrates that there exists a statistically significant long-run negative relationship between inflation and economic growth for the country as indicated by a statistically significant long-run negative relationship between CPI and real GDP. Afzal[5] examined that financial integration do not have short-run impact on economic growth. Long run equilibrium relationship is founded between economic growth and GDP. Public sector investment and private investment stimulate each other that in turn benefit the economic growth. Chew examined the short-run and long-run dynamic interactions between exports, imports and income for Pakistan within a multivariate framework. He also suggest that with the used of imports as an additional relevant variable in the empirical model, the researchers can have a better understanding on the effects of exports on economic growth. However, that study doesn't find evidence to support importled growth and export-led growth hypotheses in the long-run. In the short-run, this study finds evidence to support exportled growth, growth-led exports, import-led growth and growth-led imports hypotheses. This study suggested that exports and imports are important in fueling the economic growth of Pakistan in the short run[44].

Aurangzeb[14]investigated the relationship between exports and economic growth in Pakistan by utilizing the analytical framework. The hypothesis that marginal factor productivities are not equal in export and non-export sectors of the Pakistan economy is tested by using time series from 1973 to 2005 . Their study estimation results indicated that marginal factor productivities significantly higher in the export sector. Moreover, the difference seems to derive, in part, from intersectoral positive externalities generated by the export sector. In broad terms, therefore, the results of their study supportive of the export oriented, outward-looking approach to trade relations adopted by policymakers over the past decade. Andros and Sugata [13] examined the impact of government expenditure on growth, in a heterogeneous panel for Fifteen (15) developing countries. With the help of GMM techniques, study showed that countries with substantial government expenditure have strong growth affects, which vary considerably across the nations. According to some studies that were investigated in the long run, services exports do have a positive impact on GDP growth, both in developed and in developing countries. Yet, in the latter, the services exports/GDP growth nexus was severely weakened in the 1990s (to the point of becoming statistically not significant), while it grew quite strong in developed countries. A modal which consists of five variables as GDP, FDI, labor force, and gross capital formation as a percentage of GDP, which founded that Pakistan's capacity to progress on economic development will depend on performance in attracting FDI. Pourshahabi et al.[66] investigated the relationship between Foreign Direct Investment (FDI), economic freedom and growth in OECD countries during 1997-2007. Panel data Method is used to estimate two models. The first model was applied to investigate the factors that stimulate FDI and the second one was applied to find the growth factors in OECD members. The results of first model indicated that Human Capital, Market Size, Political Stability and Inflation have positive and significant impact on FDI in these set of countries. However, the effect of Economic Freedom on FDI in OECD countries is positive, but it is not significant. As to the second model they found that Foreign Direct Investment, economic freedom, Government Consumption Expenditure, public investment and Human Capital lead to growth in these countries. However, inflation and external debt have negative effect on growth but this negative effect is not significant for inflation.

Ajide [7] posits that Foreign direct investment inflows have been one of the major development financing options often rely upon by the developing countries particularly countries within the Africa sub-Saharan region to drive their stunted economies to a sustainable growth trajectory. However, in the recent times, the debates have shifted to including the degree of economic freedom as an important mediating link towards attaining the growth success. Nigeria, like many other Africa countries, has been enjoying the torrent of foreign direct investment inflows from the developed countries subject to availability of certain economic fundamentals of which economic freedom forms an integral part. He added that economic freedom is made of five components which include size of government (SG); legal structure and security of property rights (LS); access to sound money (AM); freedom to trade internationally (FT); and regulation of credit, labor, and business (RG).

\subsubsection{Gross Domestic Product (GDP)}

Kira [48] indicated that GDP is one of the determinants of country's economic growth and identify key factors that affect the GDP of Developing Countries which includes Consumption (Government Final Expenditure and Household Final Expenditure) and Exports. He added that the Investment sector have to be encouraged for its impact on GDP to be realized including stimulation of industrialization at country level. Against the backdrop of the imperatives of finance in enhancing economic growth and development especially in developing economies like Nigeria, Onwumere et al.[65] investigated whether financial structure has positive and significant impact on economic growth and development in Nigeria. Their findings support existing literature that total financial structure has positive and significant impact on economic growth. However, while some sectors exert more influence (banking and market), other sectors (such as insurance) were found to have non-significant impact on economic growth. Adua et al.[4] investigated the long-run growth effects of financial development in Ghana and argue that the growth effect of financial development is responsive to the choice of proxy. The study hence indicated that the ratio of credit to the private sector to GDP and total domestic credit contribute to growth, while the broad money supply to GDP ratio does not promote growth. The indexes created from principal component analysis indexes validated the sensitivity of the effect to the choice of proxy. The findings suggest that regardless the financial development outcome, growth is a function of the indicator utilized as proxy for financial development.

Caporale et al [26] reviewed the main characteristics of the banking and financial sector in ten new European Union (EU) members, and then examined the relationship between financial development and economic growth in these countries. The study estimated a dynamic panel model over the period 1994 to 2007. The evidence suggested that the stock and credit markets are still underdeveloped in these economies, and that their contribution to economic growth is inadequate owing to lack of financial depth. Conversely, a 
more efficient banking sector was found to have accelerated growth. Furthermore, Granger causality test indicated a causality running from financial development to economic growth, but not in the opposite direction.

Ngongang[56] empirically analyzed the argument on the relationship between the finance and growth, using the data from 21 Sub-Saharan African countries and by employing the dynamic panel GMM technique. The result showed that there lies a positive link between financial development and economic growth. This link is strong for the subject of the financial system in Sub-Saharan Africa. On the other hand, an outcome highlighting the link between foreign direct investment and economic growth was favourable. Aye [18] investigated the causality between financial development and economic growth in Nigeria over the coverage period 19612012. A bootstrap rolling window estimation was used to evaluate Granger causality between financial deepening and economic growth over different time periods. The results revealed that there was no causality between the two series. The tests further revealed that while financial deepening has predictive influence for economic growth at some periods, economic growth has predictive control for financial deepening at some periods. Mirdala [54] analyzed the key aspects of the financial deepening in ten European transition economies (ETE) with period extending from 2000 to 2010 using vector error correction model (VECM).The results showed that countries with lower GDP per capita seem to benefit significantly from financial deepening in the short-run and financial deepening indicators Granger cause real output in the long-run, while highlighting that, overall, there is strong evidence of positive impact in all ETE.

Similarly Kargbo et al[45] analyzed financial deepening in low, middle and high income economies. The authors used financial variables in the liberalized economies of Sierra Leone, Nigeria and South Korea as low, medium and high income countries respectively between 2000 and 2008. The Ordinary Least Squares and Multiple Regression model estimation technique were employed to examine the causality between financial deepening and economic growth, and to find out their impact with emphasis also on whether the time series data are stationary or not for the countries under review. The empirical results suggested that financial sector development and economic growth are positively cointegrated, with signs for stability in long-run specifically on equilibrium relationship present within "bank based" financial deepening determinants. The results generally support the view that, financial deepening is a crucial causal factor of economic growth. Mhadhbi [53] examined the empirical relationship between financial development and economic growth within the period 1973 to 2012. Results obtained using the Generalized Method of Moments (GMM) dynamic panel show that credits granted by the financial system to the private sector has a negative influence on growth. Meanwhile, the measure that underscores the financial deepening of the economy appears to depend positively on economic growth for developing countries but negatively for developed country.

Adekunle et al [3] examined the impact of financial sector development on economic growth in Nigeria. The OLS method of the regression analysis was used; the financial development was provided by ratio of money stock to GDP (M2/GDP), real interest rate (INTR), ratio of credit to private sector to GDP (CP/GDP) while the economic growth was measured by the real GDP (RGDP). The study revealed that only the real interest rate is negatively related to growth, while all the explanatory variables were statistically non-significant. Though the overall statistic indicated that the independent variables were able to explain 74 percent variation in the dependent but contrary to theoretical expectation, it is not statistically significant. Sackey and Sackey and Nkrumah [69] examined the effects of financial deepening on Economic Growth in Ghana using the Johansen Co-integration analysis. The paper empirically examined the causal link between financial sector development and economic growth in Ghana using a quarterly time series data set on Ghana over period (2000-2009). The Johansen Co-integration technique and bivariate vector auto-regressive framework were utilized for the regression. The result of the study reveals the existence of statistically positive and significant relationship between the financial sector development and economic growth in Ghana. Nguena and Abimbola[49] employed a hypothetical-deductive theoretical approach, which is complemented by an empirical investigation in both static and dynamic panel data, as they attempted to investigate the effects of financial deepening dynamics with regards to financial policy coordination in the case of the WAEMU subregion. The underlying dynamics is apparent in the sub-region and entails that after five years, financial policies coordination would have considerable favourable impact. The study highlighted that monetary policy targeting has indirect effect on financial depth in the region.

Nzotta and Okereke [59] empirically examined financial deepening and economic development in Nigeria within the period 1986-2007. The theoretical foundation was that accelerated growth is a function of high level of financial deepening in an economy. The study used secondary data, sourced for a-22- year period. At the end of the study, it was found that financial deepening index was low in Nigeria during the period covered by the study. The authors concluded that the financial system was unable to sustain an effective financial intermediation, particularly in credit allocation and efficient monetization of the economy. Tabi et al [75] investigated the relationship between financial development and economic growth in Cameroon using time series data sourced between 1970 and 2005. They espoused that controlling variables such as government consumption, trade openness and investment rate are fundamental factors in growth equations and were able to establish a positive long run relationship between financial development and economic growth. Akingunola el al[9] adopted the Johansen method of co-integration analysis to analyse the various measures of financial development. The results showed that financial development has a positive effect on economic growth in the long run. The study also indicated that there is long term causal relationship leading from financial development to economic growth. Simwaka et al.[71] examined the causal relationship between financial development and economic growth in Malawi. The study employed the autoregressive distributed lag (ARDL) approach. Results revealed that there is positive and significant relationship between financial development and economic growth in the longrun. Granger causality tests showed a unidirectional causality and hence showed that economic growth drives financial development without feedback effects, thus financial development has no causal effects on economic growth.

Bakay [19] examined private sector credit as an indicator that affects GDP and economic growth. There was evidence of a weak relationship between economic growth and bank deposits as a ratio of GDP. These results therefore imply that economic growth is critical for development of the financial sector in Malawi. Rana and Barua [67] examined the 
relationship between financial development and economic growth using panel data for five emerging South Asian countries - Bangladesh, India, Nepal, Pakistan and Sri Lanka. The results indicate that growth of total debt services and domestic savings have significant impact on economic development of these countries.

\subsubsection{Capital market and Economic growth}

According to Al-fali [10] the capital market is a network of specialized financial institutions, series of mechanism, processes and infrastructure that, in various ways, facilitate the bringing together of suppliers and users of medium to long term capital for investment in socio-economic development projects. Abu[1] examined stock market development effects on economic growth in Nigeria and the econometric results indicate that, stock market development (that is, market capitalization, gross domestic product ratio) increase Economic growth. Odetayo and Sajuyogbe [60] examine the impact of Nigerian capital market on economic growth and development for the period 1990-2011 and it was observed that capital market indices have significant impact on the economic growth. Also, Kolapo and Adaramola [49] urged that Nigerian capital Market development has significant relationship with economic growth. While some authors have emphasized no significant or weak significant impact of Nigeria capital market on economic growth [32][34][61], others have a moderate appeal and obtained a generally satisfactory reports of influence of Nigeria Capital Market on economic growth[42][62] [74][63]. Outside Nigeria, some authors are of the view that market capitalization influences economic growth positively [39][80] [64] [55].

\subsection{Efficiency as a measure of}

\section{Financial/capital development Performance}

Several researchers have adopted various approaches for measuring the economic growth of a nation. When it comes to ascertaining the effects of economic indicators on economic growth, efficiency measures is very paramount as it seeks to justify the ratio of input vs outputs. In Škare and Rabar [73], a wide range of studies shows that economic growth is a complex macroeconomic phenomenon, which is why its sources and the extent of their influence, as well as the way of their contribution to the growth, have yet not been clearly understood, adequately conceptualized and fully explained. It could be partly attributed to the lack of a generalized or unifying theory, and the simplistic and very abstract way conventional economics approaches these issues [15]. Therefore, efforts to make progress in clarifying these questions, which implies exploring and explaining development gaps between countries, remain an important theoretical and empirical task. Over the last three decades, however, it has attracted increasing attention in both theoretical and applied empirical research. However, many of the studies in the empirical growth literature, particularly the earlier ones, have focused on capital accumulation, largely ignoring productivity growth. Also, the use of traditional growth accounting, among other limitations, usually assumes that the production technology follows the suggested CobbDouglas form. Moreover, all changes in Total Factor Productivity (TFP) are attributed to technological change.
According to Widiarto and Emrouznejad [79], traditional economic and financial ratios are not sufficient to assess financial development performance. Using traditional financial ratios to measure economic institution performance can be ambiguous i.e. these financial development can excel in one ratio but fail in others hence difficulty in overall performance benchmarking Bogetoft and Otto[23]. Furthermore, separate ratios cannot measure how different inputs concurrently affect multiple outputs in transformation process To redress all these issues, Data Envelopment Analysis (DEA) has been suggested in recent literature.

\subsection{Data Envelopment Analysis (DEA)}

DEA as a nonparametric alternative to traditional growth accounting and it is suitable for analysing productivity convergence based on frontier production functions. The use of this approach only requires the assumption about the returns to scale (RTS), and changes in TFP are decomposed into changes in the efficiency of production and technological changes. Škare and Rabar [73] added that the DEA methodology is derived from the classical microeconomic theory of production. It is used for evaluating the relative efficiency of operating entities of similar nature, i.e. of decision-making units (DMUs) that use the same multiple inputs and produce the same multiple outputs. The original question in the DEA-literature concerned the ways of measuring each unit's efficiency in production compared to a sample of peers, given observations on (possibly multiple) input and output quantities and, often, no reliable information on prices and no exact knowledge of the functional form of a production or cost function [28]. DEA has been proven to be an effective tool for performance evaluation and benchmarking since it was first introduced. In DEA models, each input or output variable is attached with a weight, and the relative efficiency of each Decision-Making Unit (DMU) is defined as the ratio of its weighted sum of outputs to the weighted sum of inputs, thus DEA efficiencies are relative to the set of input-output data available. The nature of the DEA method allows each DMU under evaluation to maximize its relative efficiency by discretionarily choosing its weight based upon a set of constraints that all the efficiencies of DMUs are not bigger than one.

Accordingly, at a given number of DMUs, the efficiency score of each DMU relies heavily on the dimensionality of the weight space. Adding variables to a DEA model will result in higher dimensionality of the weight space and higher efficiency scores as well as expanded set of efficient DMUs [29]. In other words, the greater the number of variables a DEA model has, the more efficient DMUs will be and the less discerning the DEA analysis [43]. This situation suggests the need for selecting as few variables for DEA models as possible. DEA excels in assessing efficiencies without $a$ priori assumption on the distribution and production function [30][28] thus shines in situation where inputs-outputs relatioship is not straightforward. Consequently, DEA is an appropriate method for economic growth assessment whereby functional relationship between multiple inputs and output(s) therein are often not directly observable. In any economic system, a DEA can be model as shown in figure 1 . 


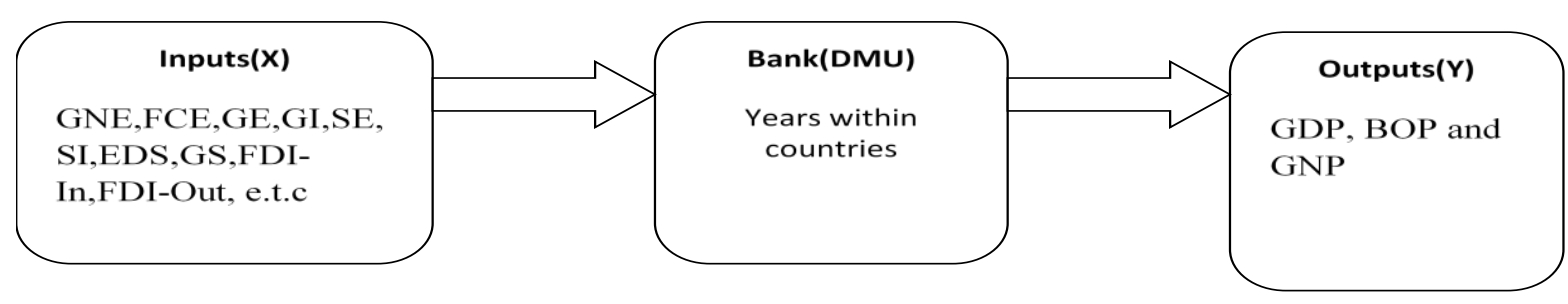

Figure 1: A Generic DEA Structure Adopted and Modified

\subsection{DEA and Fuzzy-DEA Model}

DEA models: Two approaches in basic DEA models are input-orientated, i.e. maximises proportional inputs reduction whilst holding outputs constant, and output-orientated, which maximises the proportional outputs increase whilst keeping inputs. Also, two basic DEA models are Charnes, Cooper and Rhodes (CCR) model and Banker, Charnes and Cooper(BCC) model [69]. CCR model assesses technical efficiency under Constant Return to Scale (CRS) condition hence CRS model. Multiple inputs and outputs for a given DMU are linearly aggregated into single 'virtual' input and output in the following manner:

$$
\begin{aligned}
& \text { Virtual Input }=v_{1} x_{1}+. .+v_{i} x_{i}=\sum_{i=1}^{m} v_{i} x_{i} \\
& \text { Virtual Output }=u_{1} y_{1}+. .+u_{i} y_{i}=\sum_{r=1}^{s} u_{r} y_{r} \\
& \text { Efficiency }=\frac{\text { Virtual Output }}{\text { Virtual Input }}=\frac{\sum_{r=1}^{s} u_{r} y_{r}}{\sum_{i=1}^{m} v_{i} x_{i}}
\end{aligned}
$$

where $v_{i}$ and $u_{r}$ are weights for observed input $x_{i}$ and observed output $y_{r}$ respectively. Efficiency score is assigned for each DMU in a way that maximize the ratio of weighted output to weighted input. BCC model modifies CCR model by applying a more realistic assumption of Variable Returns to Scale (VRS) wherein each DMU is allowed to exhibit different returns to scale due to different environment, hence VRS model. CRS is only valid if a DMU operates at its most productive scale size yet that is often not the case. Technical Efficiency is calculated as distance of DMU to reference set on the frontier; creating relative efficiency measure for all DMUs [33]. Scale efficiency causes the difference between VRS technical efficiency of a given DMU, i.e. pure technical efficiency, to its CRS technical efficiency, i.e. global technical efficiency[77].

Pure technical efficiency scores from BCC model is thereby greater or equal to global technical efficiency scores from CCR model as DMU is measured relative to smaller number of DMUs [77].

\section{Model 1: CCR-DEA:}

$$
\begin{gathered}
\text { Max } Z=\sum_{r=1}^{s} v_{r} y_{r 0}, \quad r=1, \ldots, s, \\
\text { st } \sum_{i=1}^{m} u_{j} x_{i 0}=1, i=1, \ldots, m, \\
\sum_{i=1}^{m} u_{j} x_{i j} \geq \sum_{r=1}^{s} v_{r} y_{r j}, j=1, \ldots, N, \\
u_{i}, v_{r} \geq 0
\end{gathered}
$$

Where $u_{i}$ is the weight associate to the ith input and $v_{r}$ is the weight associate to the rth output. The target $\mathrm{DMU}\left(\mathrm{DMU}_{0}\right)$ is technically efficient if and only if $\mathrm{Z}=1$. It can be seen from model 1 that the essence of CCR model is that the $\mathrm{DMU}_{0}$ evaluated tries to find out its weight vector to maximizing its weighted output with the constraints that its weighted input is fixed as unity and the weighted output is not larger than the weighted input for all DMUs. In addition to the CCR model, other well-known DEA models include the "BCC" model, the "additive" model, the "free disposal hull" (FDH) model, and the "slacks-based measure of efficiency" (SBM) model [18].

FDEA or Fuzzy DEA models: At the turn of the present century, reducing complex real-world systems into precise mathematical models was the main trend in science and engineering. Unfortunately, real-world situations are frequently not dealing with exact data. Thus precise mathematical models are not enough to tackle all practical problems. In practice there are many problems in which, all (or some) input-output levels are fuzzy numbers. It is difficult to evaluate DMUs in an accurate manner to measure the efficiency. Fuzzy-DEA or FDEA model is a powerful tool for evaluating the performance of a set of organizations or activities under uncertain environment. Adopted from Kazemi and Alimi[47], all inputs, outputs and decision variables on the DEA are defined as fuzzy numbers. The technique proposed evaluates the relative efficiency of a set of homogenous DMUs by using a ratio of the weighted sum of outputs to the weighted sum of inputs. It generalizes the usual efficiency measurement from a single-input, single-output ratio to a multiple-input, multiple-output ratio.

Kazemi and Alimi [47] gave some definitions of fuzzy theory as follows:

a. If the universal set is defined as $\mathrm{X}$ then a fuzzy set $\tilde{A}$ of $\mathrm{X}$ can be defined by its membership function $\mu_{\tilde{A}}: \mathrm{X} \rightarrow[0,1]$ Where for each $\mathrm{x} \in \mathrm{X}, \mu_{\tilde{A}}(\mathrm{x})$ is a real number in interval $[0,1] . \mu_{\tilde{A}}(\mathrm{x})$ shows the grade of membership function of $\mathrm{x}$ in $\tilde{A}$. The fuzzy subset of $\tilde{A}$ can be written as a set of pairs of element $\mathrm{x}$ and $\mu_{\tilde{A}}(\mathrm{x})$

$\tilde{A}=\mathrm{x}, \mu_{\tilde{A}}(\mathrm{x}) \mathrm{x} \in \mathrm{X}$

b. The $\alpha$ - cut set of a fuzzy set like $\tilde{A}$ is defined as a set like $[\tilde{A}]_{\alpha}$ in which the degree of its membership function is more than the value of $\alpha$

$[\tilde{A}]_{\alpha}=\left\{\mathrm{x} \mid \mu_{\tilde{A}}(\mathrm{x}) \geq \alpha, \alpha \in[0,1]\right\}$

c. A fuzzy set $\tilde{A}$ in $\mathrm{X}=\mathrm{R}^{\mathrm{n}}$ is a convex fuzzy set if and only if all its $\alpha$ - cut sets are convex.

d. A fuzzy set $\tilde{A}$ in $\mathrm{X}$ is a normal fuzzy set if there is a $\mathrm{x} \in \mathrm{X}$ in which $\mu_{\tilde{A}}(\mathrm{x})=1$.

e. A fuzzy number is a continuous, convex and normal fuzzy set of the real line of $\mathrm{R}^{1}$.

f. A fuzzy number $L$ is said to be positive (negative) if $\mu_{\mathrm{L}} \mathrm{x}=0, \forall \mathrm{x}<0(\forall x>0)$. For example $(1,3,7)$ is a positive number, $(-7,-5,-1)$ is a negative number and $(-3,1,5)$ is neither positive nor negative [26].

g. A fuzzy number $\widetilde{A}=(\mathrm{f}, \mathrm{g}, \mathrm{h})$ is called a triangular fuzzy number if its membership function is given by: 


$$
\mu_{\tilde{A}}(X)=\left\{\begin{array}{cc}
\frac{x-f}{g-f} & f \leq x \leq g \\
\frac{x-h}{g-h} & g \leq x \leq h \\
0 & \text { otherwise }
\end{array}\right.
$$

Where $\mathrm{x}$ is a parameter value

h. Two triangular fuzzy numbers $\tilde{A}=(\mathrm{f}, \mathrm{g}, \mathrm{h})$ and $\tilde{B}=$ (p, q, r) are said to be equal iff $\mathrm{f}=\mathrm{p}, \mathrm{g}=\mathrm{q}$ and $\mathrm{h}=\mathrm{r}$.

i. A function $R: F(R) \rightarrow R$ is a ranking function where $F(R)$ includes a set of fuzzy numbers that is defined on the set of real numbers. This function maps each fuzzy number into the real line. Let $\tilde{A}=$ (f, g, h) be a triangular fuzzy number then $\Re(\tilde{A})=$ $\frac{f+2 g+h}{4}$

j. Let numbers $\tilde{A}=(\mathrm{f}, \mathrm{g}, \mathrm{h})$ and $\tilde{B}=(\mathrm{p}, \mathrm{q}, \mathrm{r})$ be two triangular fuzzy numbers then we perform arithmetic operations on $\tilde{A}$ and $\tilde{B}$ as foolows:

a. $\tilde{A} \oplus \widetilde{B}=(\mathrm{f}, \mathrm{g}, \mathrm{h}) \oplus \mathrm{p}, \mathrm{q}, \mathrm{r}=(\mathrm{f}+\mathrm{p}, \mathrm{g}+\mathrm{q}, \mathrm{h}+\mathrm{r})$

b. $-B=-(\mathrm{p}, \mathrm{q}, \mathrm{r})=(-\mathrm{r},-\mathrm{q},-\mathrm{p})$

c. $\quad \tilde{A} \ominus B=\mathrm{f}, \mathrm{g}, \mathrm{h} \ominus \mathrm{p}, \mathrm{q}, \mathrm{r}=\mathrm{f}-\mathrm{r}, \mathrm{g}-\mathrm{q}, \mathrm{h}-\mathrm{p}$

d. Let $\tilde{A}=(\mathrm{f}, \mathrm{g}, \mathrm{h})$ be a triangular fuzzy number and $B=(\mathrm{x}, \mathrm{y}, \mathrm{z})$ be a positive triangular fuzzy number then we have:

$$
\tilde{A} \otimes \tilde{B} \simeq=\left\{\begin{array}{lc}
(f x, g y, h z) & f \geq 0 \\
(f z, g y, h z), & f<0, h \geq 0 \\
(f z, g y, h x) & f<0
\end{array}\right.
$$

Model 2: FDEA Model:

The FDEA model is a fuzzified CCR-DEA model and it is given as

$$
\begin{gathered}
\operatorname{Max} Z=\sum_{r=1}^{s} v_{r} \tilde{y}_{r 0}, \quad r=1, \ldots, s, \\
\text { st } \sum_{i=1}^{m} u_{j} \tilde{x}_{i 0}=1, i=1, \ldots, m, \\
\sum_{i=1}^{m} u_{j} \tilde{x}_{i j} \geq \sum_{r=1}^{s} v_{r} \tilde{y}_{r j}, j=1, \ldots, N, \\
u_{i}, v_{r} \geq 0
\end{gathered}
$$

Where $\tilde{x}_{i j}$ and $\tilde{y}_{r j}$ are respectively the ith fuzzy input used and the rth fuzzy output produced by $\mathrm{DMU}_{\mathrm{j}}$. The interpretation of constraints of FDEA model is similar to the crisp CCR -DEA model. The difference between the two models resides on the manner of resolution. The CCR-DEA model can be simply solved by a standard LP solver. For the FDEA model, the resolution is more difficult and requires some ranking methods for ranking fuzzy sets.

\section{METHODOLOGY}

To perform a robust study of this magnitude, the exploratory method was used. This research plan was conducted as shown in figure 3.

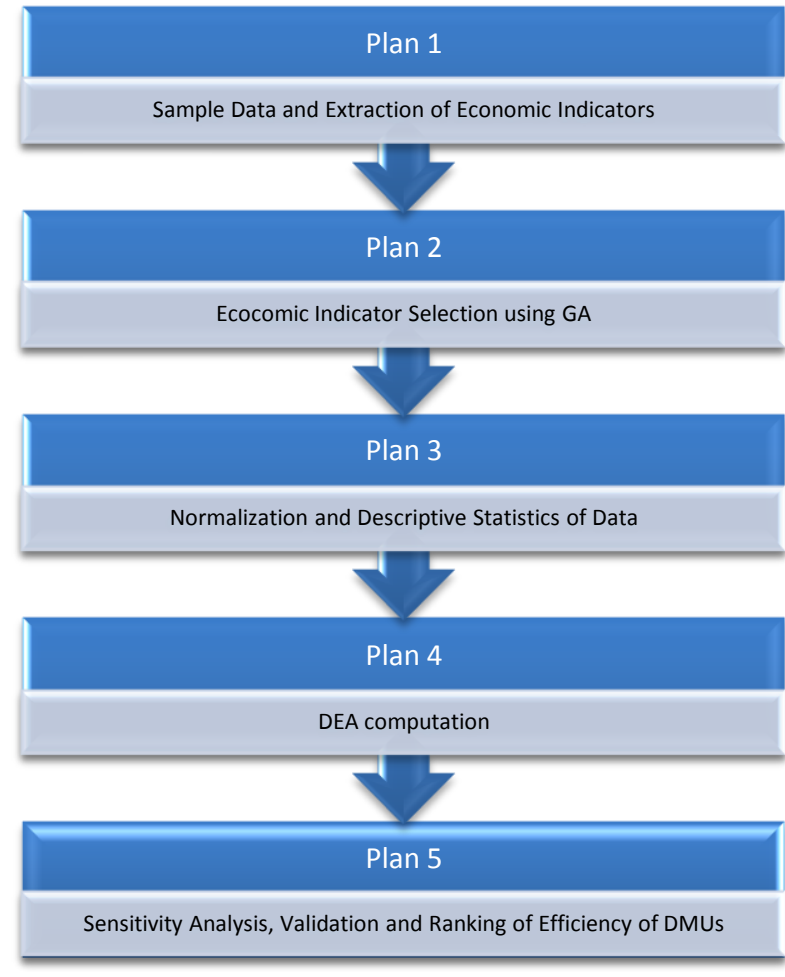

Figure 2: Proposed Research plan

\subsection{Plan 1: Sample Data and Extraction of Economic Indicators}

Economic indicators that affect Economic growths were captured as inputs and outputs. The source of data used in this research was secondary data extracted from reports of World Bank database, International Monetary Fund (IMF), Central Banks and Stock exchange market of countries under survey as published annually. The countries used in this study comprise of fourteen (14) ECOWAS countries. The choice of these countries was based on the ground of having a complete appraisal of different types of economic policies and financial development within a single context as they in one way or the other affects/influence the economic growth of respected member nation. The ECOWAS countries are: Benin, Burkina Faso, Cameroon, Cote d'Ivoire, Gambia, Ghana, GuineaBissau, Liberia, Mali, Niger, Nigeria, Senegal, Sierra Leone, and Togo. The extracted data from World Bank database was from 1999 to 2015. The rationales behind the use of secondary data were to critically identify the years where the country economic growth under study was efficient or optimal and was the years with complete data for the parameters required for measuring countries efficiency.

\subsection{Plan 2: Economic Indicator Selection using Genetic Algorithm}

Genetic Algorithm is one of the most efficient optimization search algorithm used to search through complex data set and it helps to provide the best subset or variables among the input and outputs that will contribute the most in efficiency measure. GA consists of three components (1) Chromosomes (ii) fitness function and genetic operators i.e. mutation and crossover[72]. Searching appropriate subset from the data set was performed as described in Madhanagopal and Chandrasekaran [51] using Relative/Root Mean (RM) coefficient. The RM coefficient is given in equation 1 
$R M=\operatorname{corr}\left(X, P_{k} X\right)=\sqrt{\frac{\operatorname{tr}\left(X^{i} P_{k} X\right)}{\operatorname{tr}\left(X^{i} X\right)}}=\sqrt{\frac{\sum_{i=1}^{p} \lambda_{i}\left(r_{m}\right)_{i}^{2}}{\sum_{j=1}^{p} \lambda_{j}}}=$ $\sqrt{\frac{\operatorname{tr}\left(\left[\left[S^{2}\right] \rrbracket_{(k)} S_{k}^{-1}\right)\right.}{\operatorname{tr}(S)}} \ldots$. equation 1

Where:

Corr=correlation matrix; $\operatorname{tr}=$ trace of matrix; $X$ is the full data matrix; $S=\frac{1}{n} X^{i} X$ is $\mathrm{p} \mathrm{x} \mathrm{p} \mathrm{covariance} \mathrm{or} \mathrm{correlation} \mathrm{matrix} \mathrm{of}$ the full data set; $\mathrm{K}$ denotes the index set of $\mathrm{k}$ variable in the variable subset; $\mathrm{P}_{\mathrm{k}}$ is the orthogonal projection matrix of the subspace spanned by a given $\mathrm{k}$-variable subset; $\mathrm{S}_{\mathrm{k}}$ is the $\mathrm{k} \mathrm{x} \mathrm{k}$ principle submatrix of matrix $\mathrm{S}$ which results from retaining the rows/columns whose indices belong to $\mathrm{k} ;\left[\left[S^{2}\right] \rrbracket_{(k)}\right.$ is the $\mathrm{k} x \mathrm{k}$ principle submatrix of $\mathrm{S}^{2}$ obtained by retaining the rows/columns associated with set $\mathrm{k} ; \lambda_{i}$ stands for the $\mathrm{i}$-th largest eigenvalue of the covariance or correlation matrix defined by X; rm stands for the multiple correlation between $\mathrm{i}$-th principle component of the full data set and the $\mathrm{k}$ variable subset.

RM coefficient measures the quality of variable subset as adopted from Cadima et al., [25]. The RM coefficient which lies between 0 and 1 is a weighted average of the multiple correlations between each principal component of the full data and $\mathrm{k}$ subset variable [51]. The more RM coef approaches 1 , the higher the proportion of explained variance and vise visa.

\subsection{Plan 3: Descriptive Statistics, Fuzzification, and Normalization of Data}

Descriptive Statistics: The important of exploring and describing the dataset cannot be overemphasize. Having collected the data, it is necessary to describe and explore the data. The 'explore data' task typically consists of an initial report with summarisation and possibly visualisation of data. Although visualisation is limited to two or three dimensions, this frequently brings additional insights [32] . Besides a brief description the 'describe data task' contains notification of the type of data (e.g., continuous or discrete) because different models can be adapted depending on the data type[25]

Fuzzification: For dataset with likert scale, fuzzy number or uncertainty/risk factor, fuzzification of Data transforms selected subset of data (crips) into fuzzy number using Triangular Membership (TrFM) function. The data collected therefore need to be normalizing to reduce decision errors [34][76]. TrFM consist of triple values $\left(\pi^{1}, \pi^{\mathrm{m}}, \pi^{\mathrm{u}}\right)$ where $\pi^{1}$ and $\pi^{\mathrm{u}}$ are the Lower control limit (LCL or left side) and Upper Control Limit(UCL or right sides) at any confidence interval specified as the $\boldsymbol{\alpha}$-cut) respectively for a particular selected variable and $\pi^{\mathrm{m}}$ is the centroid or mean value of the variable [71] The triple values and the alpha cut ( $\boldsymbol{\alpha}$-cut) values control the upper bound (U) and lower bound (L) of the TrFM for each selected variable (see equation 2 and 3 and definition 1). The alpha cut introduces various level of risk and this will allow the model to accommodate the uncertain or dynamic economic influence set in by risk and varying monetary policies.

$$
\begin{aligned}
L & =\pi^{l}+\alpha\left(\pi^{m}-\pi^{l}\right) \ldots \ldots \ldots \ldots \ldots \ldots \ldots \ldots \text { equation } 2 \\
U & =\pi^{u}+\alpha\left(\pi^{u}-\pi^{m}\right) \ldots \ldots \ldots \ldots \ldots \ldots \ldots \ldots \text { equation } 3
\end{aligned}
$$

Definition 1: A fuzzy number $\mu$ for a particular attribute or variable $X$ is called a triangular fuzzy number if its membership functions $\mu(\mathrm{X})$ has the following form:

$$
\mu(x \text { or } y)=\left\{\begin{array}{cc}
\frac{x-\pi^{\mathrm{l}}}{\pi^{\mathrm{m}}-\pi^{\mathrm{l}}} & \pi^{\mathrm{l}} \leq x \leq \pi^{\mathrm{m}} \\
\frac{x-\pi^{\mathrm{m}}}{\pi^{\mathrm{u}}-\pi^{\mathrm{m}}} & \pi^{\mathrm{m}} \leq x \leq \pi^{\mathrm{u}} \\
0 & \text { otherwise }
\end{array}\right.
$$

Using Area under normal curve, $\boldsymbol{\alpha}$-cut lies between these range

$$
0 \leq \boldsymbol{\alpha}-\text { cut }<1
$$

For $\boldsymbol{\alpha}$-cut $=<0.01(99.73 \%)$, parameters $\pi^{1}=\mu-3 \sigma$ and $\pi^{\mathrm{u}}=$ $\mu+3 \sigma$

For $\boldsymbol{\alpha}$-cut $=0.05(95 \%)$, parameter $\pi^{1}=\mu-2 \sigma$ and $\pi^{\mathrm{u}}=\mu+$ $2 \sigma$

For $\boldsymbol{\alpha}$-cut $>0.1(68.26 \%)$, parameter $\pi^{\mathrm{l}}=\mu-\sigma$ and $\pi^{\mathrm{u}}=\mu+$

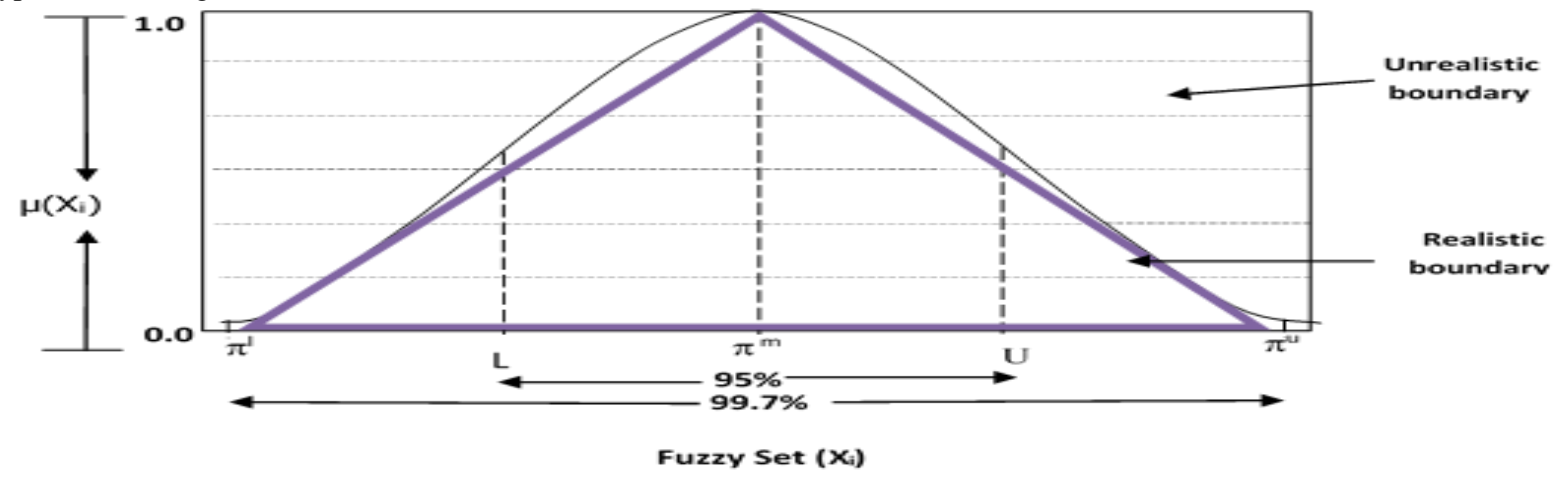

Fig 1: Membership Function

Inputs $\left(\mathrm{X}_{\mathrm{i}}\right)$ and outputs $\left(\mathrm{Y}_{\mathrm{i}}\right)$ are fuzzified using the TrFM. Figure 4 depict the fuzzy TrFM. The figure exhibits both the symmetric triangular and normal distribution. The larger the spread (standard deviation) the more it tend to be bell or normal distribution. The smaller the spread, the more it tends towards symmetric triangular distributions which are very usefully in risk management and changing market prices evaluation. The spread can also be control by the money policy put in place by government. As you can see, a variable can assume any position and will affect the performance of the production institution or unit. This fuzzification of data was implemented using Fuzzy Numbers r package.

Normalization: Efficiency estimation with noisy data (e.g., due to measurement errors) could result in very imprecise results (for various models dealing with irregular data in DEA [73]. Therefore, it is worthwhile to examine the noise around the DEA estimates by bootstrapping techniques or statistical 
inferences [62] For the aim of this research, equation 4 below is used for data normalization of the original input data.

$$
X_{\text {norm }, i}=\frac{X_{i}-X_{\min , i}}{X_{\max , i}-X_{\min , i}} \ldots \ldots \text {...equation } 4
$$

Where $X_{\text {norm }, i}$ is the normalize data for the $\mathrm{i}^{\text {th }}$ input data

$$
X_{\min , i} \text { is the minimum value of the } \mathrm{i}^{\text {th }}
$$
attribute/variable

$$
X_{\max , i} \text { is the maximum value of the } \mathrm{i}^{\text {th }}
$$

attribute/variable

$$
X_{i} \text { is the } \mathrm{X} \text { value of the } \mathrm{i}^{\text {th }} \text { attribute/variable }
$$

Assuming variable $\mathrm{X}$ represent a variable having any of these values 1,0 , and -1 representing high, normal and abnormal respectively, then the normalized data of $\mathrm{X}$ is

If $\mathrm{x}$ is 1 ,

If $\mathrm{X}=0$;

$$
\text { If } X=-1 \text {; }
$$

$$
\begin{aligned}
& X_{\text {norm }, 1}=\frac{1--1}{1--1}=1 \quad X_{\text {norm }, 0}=\frac{0--1}{1--1}=0.5 \\
& X_{\text {norm },-1}=\frac{-1--1}{1--1}=0
\end{aligned}
$$

The data normalization module helps to reduce noise and make different production entities of different sizes become homogenous, comparable and produces better results for effective decision [76][10]

\subsection{Plan 4: DEA computation.}

The efficiency scores comprising of the technical and scale efficiency are computed using various alpha-cut values ( $\boldsymbol{\alpha}$ cut). The alpha cut approach was adopted due to it intuitive appeal to estimate the efficiency values. $\boldsymbol{\alpha}$-cut is assumed to have any value between 0 and 1 . If $\boldsymbol{\alpha}$-cut $=0$, it means there is high risk of volatility of the fuzzy data and it lies in $99 \%$ confidence interval. When $\boldsymbol{\alpha}$-cut $=1$, this is zero risk volatility, therefore the fuzzy data is stable and lies within the $68 \%$ confidence interval. This will be implemented using the Benchmarking $r$ package [23].

\subsection{Plan 5. Ranking and Validation of Efficiency of DMUs}

In Evaluating performance, a DMU is fully (100\%) efficient if and only if both the efficiency score equals 1 and all slacks is equal to zero. While a DMU whose DMU efficiency score equals 1 but not all it slacks equals zero is weakly efficient.

The Spearman test of correlation (rho) was employed to verify the results of proposed models. Correlation coefficient describes both the strength and the direction of the relationship between two variables. Its value range from -1 to +1 , where 1 is total positive correlation, -1 is total negative correlation and 0 is no correlation. The rho coefficient is often used to evaluate relationship between ranked variables rather than the raw data. In this study, Spearman (rho) test was employed to compare proposed GA-FDEA models with results of CRS-DEA and BCC-models. To measure the Spearman correlation coefficient, the efficiency scores of DMUs of all models generated were ranked.

\subsection{Framework for Efficiency Measurement of Economic Growth}

3.6.1 Efficiency Measurement

Efficiency in economic theory refers to the utilization of inputs into outputs. In macroeconomic, it refers to optimum performance of a unit or institution or country. It concerns with optimal combination of inputs to produce maximum outputs or producing given outputs with least quantity of inputs hence minimizing waste. The concept of efficiency can be viewed from three perspective[35]

Technical efficiency (TE) deals with utilization of inputs to produce outputs relative to best practices in organizations with similar characteristics [33] and it measure the extent of wasted resources from transformation process (Masiye et al., 2006). TE estimates the gross efficiency of a DMU. A typical CCR or CRS model implements TE.

Pure Technical Efficiency (PTE) takes into account the assumption of variation return to scale. BCC or VRS models measure PTE

Scale efficiency (SE) reflects the potential productivity than can be gained to achieving optimum size of an DMU. It is calculated using equation 5 .

$$
S E=\frac{T E}{P T E} \ldots \ldots \text {...equation } 5
$$

Cost or economic efficiency (CE) is the combination of technical and allocative efficiency and it measures organization's ability to produce without waste and to allocate resources in their highly valued use. CE Estimates the input and/or output that minimize cost, maximize revenue or maximize profit in the context of a DEA technology[22]

$$
C E=\frac{o p t X * P^{\prime}}{X * P^{\prime}} \ldots \ldots \text { equation } 6
$$

Where OptX is the optimum input matrix or vector used in the course of production, $\mathrm{X}$ is the general inputs employed by the organization or institution or country and $P^{\prime}$ is the transpose of the prices of goods or crude oil prices.

Allocative efficiency (AE) calculates whether resources have been allocated to produce outputs with highest possible value, i.e. with lowest possible cost and it indicate the influence of input prices (see equation 7).

$$
A E=\frac{C E}{T E} \ldots \ldots \text {...equation } 7
$$

Where CE is the cost efficiency and TE is the technical efficiency

An organization, institution or country can only reach overall cost or economic efficiency if it has attained both technical and allocative efficiency [77]

\subsubsection{Research Variables}

The main goal of the research is to develop a dynamic model that measures the efficiency of economic growth of a country based on best subset of economic indicators inputs used to produce certain output (GDP).

\section{Definition of sample variables/ Indicators}

In most efficiency studies, two main approaches for selecting inputs and outputs variables in DEA are production and intermediation approach. Where the formal approach defines an institution's especially bank activity as production of 
services and views the banks as using physical inputs such as labor and capital to provide deposits and loans accounts and is more suitable for the analysis of bank branch efficiency, the later approach views banks as the intermediating funds between savers and investors. The Intermediation approach is more suitable for evaluating various and different institutions within the same domain [51][34] and it will be adopted in this research.

Endogenous Indicators/variables of economic growth

The endogenous variable of our model are GDP (Current USD), GDP per capita (Constant 2005 USD) and GNI (Current USD). They represent the output variable of our model (Variable 30, 31, and 32).

\section{Exogenous Indicators of financial development}

The two main functions of a financial system are to collect and allocate financial resources. In order to capture the development of the financial sector with respect to these two functions, we make use of the following four exogenous indicators.

i. Bank Size/Concentration depth of the financial sector: this indicator captures the total size of the financial sector with respect to the whole economy. This is equal to currency plus demand and interest bearing liabilities of banks and other financial intermediaries divided by GDP. This is represented by GFDD.OI.01 in table 1 (variable 3).

ii. Bank credit allocated to private enterprises by the financial sector: this indicator captures the allocative efficiency of the financial sector. This is represented by GFDD.SI.04 in table 2 (variable 5).

iii. Control variables Control variables are made up of the main determinants of economic growth (variable 4,6 to 29).

iv. Variable with risk or linguistic values: Investment on Information Systems \& Security (Variable 1 ) express the level of commitment of both government and international bodies on security of life and properties in the country. It assumes linguistic values of 1, 2 and 3 for Low, High, and Very High respectively. Openess of Trade/Economic Freedom (Variable 2) represents the easiness of doing business in the country due to government policies. It linguistic values of 1,2 and 3 for Unfavourable, Fair, and Good respectively.

Variable 3 and 5 determine the level of financial development of financial sector and also they influence the economic development of any society/economy.

\section{Table 1. Operationalization of Research Variables}

\begin{tabular}{|c|c|c|c|c|}
\hline $\mathrm{S} / \mathrm{N}$ & Economic Variables & Indicator Code & $\begin{array}{l}\text { Variable } \\
\text { code }\end{array}$ & Type \\
\hline 1 & Investment on Information Systems \& Security(1-Low, 2-High, 3-Very High) & GFDD.EF.01 & var1 & Input \\
\hline 2 & Openess of Trade/Economic Freedom (Unfavourable, Fair, and Good) & GFDD.EF.02 & var2 & Input \\
\hline 3 & Bank concentration $(\%)$ & GFDD.OI.01 & var3 & Input \\
\hline 4 & Bank cost to income ratio $(\%)$ & GFDD.EI.07 & var4 & Input \\
\hline 5 & Bank credit to bank deposits $(\%)$ & GFDD.SI.04 & $\operatorname{var5}$ & Input \\
\hline 6 & Bank deposits to GDP $(\%)$ & GFDD.OI.02 & var6 & Input \\
\hline 7 & Bank net interest margin $(\%)$ & GFDD.EI.01 & var7 & Input \\
\hline 8 & Bank noninterest income to total income (\%) & GFDD.EI.03 & var8 & Input \\
\hline 9 & Bank overhead costs to total assets $(\%)$ & GFDD.EI.04 & var9 & Input \\
\hline 10 & Bank return on assets $(\%$, after tax $)$ & GFDD.EI.05 & var10 & Input \\
\hline 11 & Bank return on equity $(\%$, after tax $)$ & GFDD.EI.06 & var11 & Input \\
\hline 12 & Central bank assets to GDP (\%) & GFDD.DI.06 & var12 & Input \\
\hline 13 & Consolidated foreign claims of BIS reporting banks to GDP $(\%)$ & GFDD.OI.14 & $\operatorname{var} 13$ & Input \\
\hline 14 & Consumer price index $(2010=100$, average $)$ & GFDD.OE.02 & var14 & Input \\
\hline 15 & Credit to government and state owned enterprises to GDP (\%) & GFDD.EI.08 & $\operatorname{var} 15$ & Input \\
\hline 16 & $\begin{array}{l}\text { Deposit money bank assets to deposit money bank assets and central bank assets } \\
(\%)\end{array}$ & GFDD.DI.04 & var16 & Input \\
\hline 17 & Deposit money banks' assets to GDP $(\%)$ & GFDD.DI.02 & var17 & Input \\
\hline 18 & Domestic credit to private sector (\% of GDP) & GFDD.DI.14 & var18 & Input \\
\hline 19 & $\begin{array}{l}\text { External loans and deposits of reporting banks vis-à-vis all sectors (\% of domestic } \\
\text { bank deposits) }\end{array}$ & GFDD.OI.12 & var19 & Input \\
\hline 20 & Financial system deposits to GDP $(\%)$ & GFDD.DI.08 & var20 & Input \\
\hline 21 & Life insurance premium volume to GDP $(\%)$ & GFDD.DI.09 & $\operatorname{var} 21$ & Input \\
\hline 22 & Liquid assets to deposits and short term funding (\%) & GFDD.SI.06 & var22 & Input \\
\hline 23 & Liquid liabilities in millions USD (2000 constant) & GFDD.OI.07 & $\operatorname{var} 23$ & Input \\
\hline 24 & Liquid liabilities to GDP (\%) & GFDD.DI.05 & $\operatorname{var} 24$ & Input \\
\hline 25 & Loans from non resident banks (amounts outstanding) to GDP (\%) & GFDD.OI.09 & $\operatorname{var} 25$ & Input \\
\hline
\end{tabular}




\begin{tabular}{|c|c|c|c|c|}
\hline 26 & Nonlife insurance premium volume to GDP (\%) & GFDD.DI.10 & var26 & Input \\
\hline 27 & Population (Total) & SP.POP.TOTL & var27 & Input \\
\hline 28 & Private credit by deposit money banks to GDP (\%) & GFDD.DI.01 & $\operatorname{var} 28$ & Input \\
\hline 29 & Remittance inflows to GDP (\%) & GFDD.OI.13 & var29 & Input \\
\hline 30 & GDP (Current USD) & NY.GDP.MKTP.CD & $\operatorname{var} 30$ & Output \\
\hline 31 & GDP per capita (Constant 2005 USD) & NY.GDP.PCAP.KD & var31 & Output \\
\hline 32 & GNI (Current USD) & NY.GNP.MKTP.CD & var32 & Output \\
\hline
\end{tabular}

Source: World bank (2018)

Determination of Sample Size: inputs and outputs is a major challenge analyst encounter in modeling any economic system/institutions efficiency. Since DEA results are influenced by the size of the sample, two thumb rules suggested by (Cooper et al., 2007) is expressed in equation 8 $n \geq \max ((I * O), 3(I+O)) \ldots \ldots \ldots$. Equation 8

Where $\mathrm{n}$ is sample size, $\mathrm{I}$ and $\mathrm{O}$ for Inputs and outputs variables respectively.

Rule 1: the sample size (n) must be greater than or equal to the product of Input and output i.e 29 x $3=87$.

Rule 2: the sample size (n) must be greater than or equal to 3 times the sum of the Inputs and Output i.e $3(29+3)=96$

Therefore, sample size is 448 i.e countries (14) multiply by 32 variables far exceed the required sample size and this complies with those rules.

\section{RESULTS}

\subsection{Program output and Data Analysis.}

The results from running this $\mathrm{R}$ script were exported to Microsoft Excel worksheet. The following section describes statistical and efficiency results.

\subsubsection{Inputs and Outputs Selection Framework}

Selecting appropriate variables (inputs and outputs) from the dataset is very crucial because it influence the decision making process (see table 1). Before selecting the final best variables subset, correlation matrix of all variables were determined and trimmed so as to remove any variable(s) that causes negative Eigen value (See appendix M1). The best of inputs and outputs variables were selected/implemented using Genetic Algorithm with RM coefficient (see equation 1). The sets of variables returned are influenced by the minimum Genetic Algorithm diversity (minGADiv) specified. Here we specify minGADiv as 4 which produces 3 groups (4-1) of various variable combinations with their respective RM coef (table 2). All RM coefficients approach 1 showing higher variance among the data. The GA-FDEA model will be evaluated based on variables extracted from the interception set of all 3 set groups in table 2 .

Table 2. Best Variables Matrix from GA using minGADiv=4

\begin{tabular}{|l|r|r|r|r|r|r|r|r|r|r|r|r|r|r|r|r|r|}
\hline Group & \multicolumn{1}{l|}{1} & \multicolumn{1}{l|}{3} & 3 & 4 & 5 & 6 & 7 & 8 & 9 & 10 & 11 & 12 & 13 & 14 & 15 & 16 & 17 \\
\hline 1 & 1 & 2 & 3 & 4 & 5 & 7 & 8 & 9 & 10 & 11 & 12 & 13 & 14 & 15 & 16 & 17 & 18 \\
\hline 2 & 1 & 2 & 3 & 4 & 5 & 7 & 8 & 9 & 10 & 11 & 12 & 13 & 14 & 15 & 16 & 17 & 18 \\
\hline 3 & 1 & 2 & 3 & 4 & 5 & 7 & 8 & 9 & 10 & 11 & 12 & 13 & 14 & 15 & 16 & 17 & 18 \\
\hline
\end{tabular}

\begin{tabular}{|c|c|c|c|c|c|c|c|c|c|c|c|c|}
\hline 18 & 19 & 20 & 21 & 22 & 23 & 24 & 25 & 26 & 27 & 28 & 29 & RM Coeff \\
\hline 19 & 20 & 21 & 23 & 24 & 25 & 26 & 28 & 29 & 30 & 0 & 0 & 0.998548 \\
\hline 19 & 20 & 21 & 23 & 24 & 25 & 26 & 27 & 28 & 29 & 30 & 0 & 0.999107 \\
\hline 19 & 20 & 21 & 22 & 23 & 24 & 25 & 26 & 27 & 28 & 30 & 31 & 0.999635 \\
\hline
\end{tabular}

Using set theory, let determine the interception of two sets.

Let $\quad \mathrm{A}_{\mathrm{j}}=$ Group $j \cap$ Group $j+1$,

$$
\mathrm{A}_{\mathrm{j}+1}=\operatorname{set} A_{i} \cap \text { set } j+1
$$

Where $\mathrm{j}=1$ to $3, \mathrm{i}=$ interception of two sets.

$$
\begin{gathered}
A_{1}=\text { Group } 1 \cap \text { Group } 2 \\
=\left\{\begin{array}{c}
1,2,3,4,5,7,8,9,10,11,12,13,14,15,16,17 \\
18,19,20,21,23,24,25,26,28,29,30
\end{array}\right\} \\
A_{2}=\text { set } A_{1} \cap \text { Group } 3 \\
=\left\{\begin{array}{c}
1,2,3,4,5,7,8,9,10,11,12,13,14,15,16,17,18,19 \\
20,21,23,24,25,26,28,30
\end{array}\right\}
\end{gathered}
$$

The extracted variables based on set A2 were: GFDD.EF.01, GFDD.EF.02, GFDD.OI.01, GFDD.SI.04, GFDD.EI.07, GFDD.EI.01， GFDD.EI.03， GFDD.EI.04， GFDD.EI.05, GFDD.EI.06, GFDD.DI.06, GFDD.OI.14, GFDD.OE.02, GFDD.EI.08, GFDD.DI.04, GFDD.DI.02, GFDD.DI.14, GFDD.OI.12, GFDD.DI.08, GFDD.DI.09, GFDD.OI.07,
GFDD.DI.05，GFDD.OI.09， GFDD.DI.10， GFDD.DI.01, NY.GDP.MKTP.CD

Variables removed: GFDD.OI.02, GFDD.SI.06, SP.POP.TOTL， GFDD.OI.13， NY.GDP.PCAP.KD and NY.GNP.MKTP.CD

Extracted Input Variables list: For input variables, GFDD.OI.02, GFDD.SI.06, SP.POP.TOTL, GFDD.OI.13 was removed. Therefore, the new input variable list consist of: GFDD.EF.01， GFDD.EF.02， GFDD.OI.01， GFDD.SI.04, GFDD.EI.07， GFDD.EI.01， GFDD.EI.03， GFDD.EI.04, GFDD.EI.05, GFDD.EI.06, GFDD.DI.06, GFDD.OI.14, GFDD.OE.02，GFDD.EI.08，GFDD.DI.04，GFDD.DI.02, GFDD.DI.14, GFDD.OI.12， GFDD.DI.08， GFDD.DI.09, GFDD.OI.07, GFDD.DI.05, GFDD.OI.09, GFDD.DI.10 and GFDD.DI.01, 
Extracted Output Variables list: For output variables, NY.GDP.PCAP.KD and NY.GNP.MKTP.CD were removed. The new output list consist of the following variables: NY.GDP.MKTP.CD

\subsubsection{Fuzzification of selected Variable}

Most of the variable in the dataset are estimated values. Some variables assumed ratio value or likert scale and as such they need to be converted to fuzzy numbers. Variable GFDD.EF.01 and GFDD.EF.02 will be fuzzified

\subsubsection{Descriptive Statistics of selected} variables

Table 3 depicts a summary statistics of variables selected after using the GA search algorithm.

Table 3. Descriptive Statistics of selected variables

\begin{tabular}{|c|c|c|c|c|c|c|c|c|c|c|c|c|c|c|}
\hline & 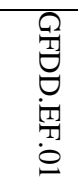 & 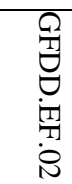 & $\begin{array}{l}\Omega \\
ٍ \\
0 \\
0 \\
0 \\
0\end{array}$ & 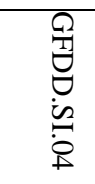 & 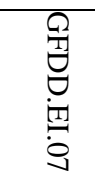 & $\begin{array}{l}\stackrel{\Omega}{0} \\
\stackrel{7}{0} \\
\stackrel{1}{0} \\
0\end{array}$ & 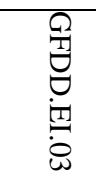 & 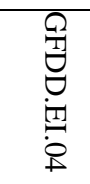 & 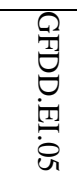 & 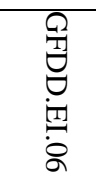 & 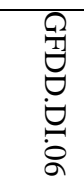 & 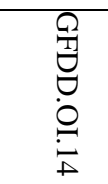 & 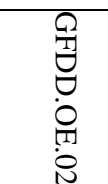 & 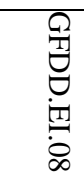 \\
\hline nobs & 254 & 254 & 254 & 254 & 254 & 254 & 254 & 254 & 254 & 254 & 254 & 254 & 254 & 254 \\
\hline NAs & 0 & 0 & 0 & 0 & 0 & 0 & 0 & 0 & 0 & 0 & 0 & 0 & 0 & 0 \\
\hline $\begin{array}{l}\text { Minimu } \\
\mathrm{m}\end{array}$ & 1 & 1 & 0 & 0 & 0 & 0 & 0 & 0 & $-\overline{4.68}$ & $\begin{array}{l}- \\
108.9 \\
1\end{array}$ & 0 & 0 & 0 & 0 \\
\hline $\begin{array}{l}\text { Maxim } \\
\text { um }\end{array}$ & 3 & 3 & 100 & $\begin{array}{l}119.2 \\
7\end{array}$ & $\begin{array}{l}218.0 \\
9\end{array}$ & 18.63 & 85.85 & 28.19 & 9.57 & $\begin{array}{l}126.1 \\
4\end{array}$ & $\begin{array}{l}234.0 \\
5\end{array}$ & 928.63 & 185.64 & 74.39 \\
\hline $\begin{array}{l}\text { l. } \\
\text { Quartil } \\
\text { e }\end{array}$ & 1 & 1 & 26.73 & 51.08 & 53.80 & 4.17 & 34.76 & 4.25 & 0.79 & 8.86 & 2.23 & 3.84 & 77.03 & 2.39 \\
\hline $\begin{array}{l}\text {. } \\
\text { Quartil } \\
\text { e }\end{array}$ & 3 & 3 & $\begin{array}{l}85.97 \\
75\end{array}$ & 90.24 & 71.05 & 8.08 & 52.5 & 7.52 & 2.34 & 23.84 & 7.40 & 16.81 & 104.81 & 7.10 \\
\hline Mean & 1.96 & 1.98 & 56.89 & 70.50 & 63.33 & 6.28 & 41.40 & 5.82 & 1.81 & 17.91 & 11.88 & 49.40 & 88.12 & 5.83 \\
\hline Median & 2.00 & 2.00 & 66.64 & 74.70 & 62.95 & 5.59 & 43.29 & 5.54 & 1.45 & 16.26 & 4.40 & 9.14 & 88.25 & 4.08 \\
\hline Sum & $\begin{array}{l}499 . \\
00\end{array}$ & $\begin{array}{l}503 . \\
00\end{array}$ & $\begin{array}{l}14450 \\
.55\end{array}$ & $\begin{array}{l}17907 \\
.55\end{array}$ & $\begin{array}{l}16086 \\
.40\end{array}$ & $\begin{array}{l}1595 . \\
00\end{array}$ & $\begin{array}{l}10514 \\
.82\end{array}$ & $\begin{array}{l}1477 . \\
16\end{array}$ & $\begin{array}{l}459 . \\
75\end{array}$ & $\begin{array}{l}4549 . \\
92\end{array}$ & $\begin{array}{l}3016 . \\
65\end{array}$ & $\begin{array}{l}12546 . \\
59\end{array}$ & $\begin{array}{l}22382 . \\
85\end{array}$ & $\begin{array}{l}1480 . \\
66\end{array}$ \\
\hline $\begin{array}{l}\text { SE } \\
\text { Mean }\end{array}$ & 0.05 & 0.05 & 2.25 & 1.61 & 1.86 & 0.23 & 1.12 & 0.20 & 0.12 & 1.19 & 1.91 & 10.75 & 1.85 & 0.49 \\
\hline $\begin{array}{l}\text { LCL } \\
\text { Mean }\end{array}$ & 1.96 & 1.98 & 56.75 & 70.40 & 63.22 & 6.26 & 41.33 & 5.80 & 1.80 & 17.84 & 11.76 & 48.72 & 88.01 & 5.80 \\
\hline $\begin{array}{l}\text { UCL } \\
\text { Mean }\end{array}$ & 1.97 & 1.98 & 57.03 & 70.60 & 63.45 & 6.29 & 41.47 & 5.83 & 1.82 & 17.99 & 12.00 & 50.07 & 88.24 & 5.86 \\
\hline $\begin{array}{l}\text { Varianc } \\
\text { e }\end{array}$ & 0.63 & 0.65 & $\begin{array}{l}1287 . \\
29\end{array}$ & $\begin{array}{l}658.3 \\
5\end{array}$ & $\begin{array}{l}874.5 \\
1\end{array}$ & 13.61 & $\begin{array}{l}320.7 \\
4\end{array}$ & 9.91 & 3.48 & $\begin{array}{l}361.3 \\
5\end{array}$ & $\begin{array}{l}924.2 \\
6\end{array}$ & $\begin{array}{l}29332 . \\
07\end{array}$ & 865.21 & 59.99 \\
\hline Stdev & 0.79 & 0.81 & 35.88 & 25.66 & 29.57 & 3.69 & 17.91 & 3.15 & 1.86 & 19.01 & 30.40 & 171.27 & 29.41 & 7.75 \\
\hline $\begin{array}{l}\text { Skewne } \\
\text { ss }\end{array}$ & 0.06 & 0.04 & -0.59 & -0.50 & 0.88 & 0.63 & -0.67 & 1.49 & 1.51 & 0.06 & 5.11 & 4.26 & -0.12 & 5.88 \\
\hline $\begin{array}{l}\text { Kurtosi } \\
\text { s }\end{array}$ & $\begin{array}{l}- \\
1.41\end{array}$ & - & -1.09 & -0.34 & 4.99 & 0.40 & 0.50 & 9.49 & 3.88 & 11.80 & 27.45 & 16.74 & 1.50 & 46.14 \\
\hline
\end{tabular}


Table 3. Descriptive Statistics of selected variables (continues)

\begin{tabular}{|c|c|c|c|c|c|c|c|c|c|c|c|c|}
\hline & 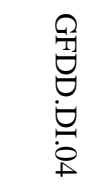 & 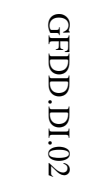 & 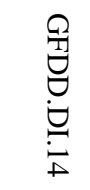 & $\begin{array}{l}\stackrel{\Omega}{0} \\
\stackrel{0}{0} \\
\stackrel{0}{N}\end{array}$ & 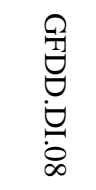 & 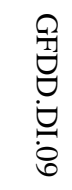 & $\begin{array}{l}\Omega \\
0 \\
0 \\
0 \\
0 \\
0 \\
0\end{array}$ & 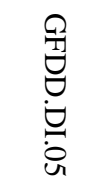 & 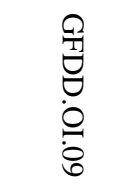 & 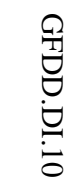 & 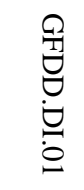 & 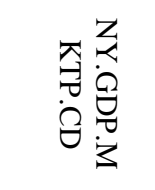 \\
\hline nobs & 254 & 254 & 254 & 254 & 254 & 254 & 254 & 254 & 254 & 254 & 254 & 254 \\
\hline NAs & 0 & 0 & 0 & 0 & 0 & 0 & 0 & 0 & 0 & 0 & 0 & 0 \\
\hline $\begin{array}{c}\text { Minimu } \\
\mathrm{m}\end{array}$ & 0 & 0 & 0 & 0 & 0 & 0 & 0 & 0 & 0 & 0 & 0 & $\begin{array}{c}224446652 \\
.1\end{array}$ \\
\hline $\begin{array}{c}\text { Maximu } \\
\mathrm{m}\end{array}$ & 99.28 & 46.17 & 38.39 & 33600.5 & 44.34 & 0.88 & 103508 & 52.68 & 3837.94 & 1.04 & 36.01 & $5.47 \mathrm{E}+11$ \\
\hline $\begin{array}{c}1 . \\
\text { Quartile }\end{array}$ & 53.15 & 11.14 & 8.33 & 30.76 & 12.62 & 0.00 & 450.00 & 18.63 & 1.85 & 0.03 & 7.28 & $\begin{array}{c}194562067 \\
4 \\
\end{array}$ \\
\hline $\begin{array}{c}3 . \\
\text { Quartile }\end{array}$ & 88.80 & 22.08 & 16.03 & 97.60 & 21.46 & 0.26 & 3511.00 & 30.39 & 9.34 & 0.62 & 16.53 & $\begin{array}{c}127654547 \\
03\end{array}$ \\
\hline Mean & 68.08 & 17.30 & 12.98 & 1028.29 & 17.06 & 0.16 & 5512.74 & 24.54 & 155.21 & 0.41 & 12.39 & $\begin{array}{c}228934835 \\
67\end{array}$ \\
\hline Median & 78.31 & 17.15 & 12.62 & 55.28 & 15.85 & 0.09 & 1522.50 & 23.38 & 4.97 & 0.45 & 12.70 & $\begin{array}{c}510487039 \\
4\end{array}$ \\
\hline Sum & $\begin{array}{c}17293 . \\
55\end{array}$ & $\begin{array}{c}4394 . \\
79\end{array}$ & $\begin{array}{c}3296 . \\
06\end{array}$ & $\begin{array}{c}261186.5 \\
4\end{array}$ & $\begin{array}{c}4332 . \\
10\end{array}$ & $\begin{array}{c}39.8 \\
6\end{array}$ & $\begin{array}{c}1400236.0 \\
0 \\
\end{array}$ & $\begin{array}{c}6233 . \\
82 \\
\end{array}$ & $\begin{array}{c}39422.5 \\
3 \\
\end{array}$ & $\begin{array}{c}102 . \\
95\end{array}$ & $\begin{array}{c}3146 . \\
99\end{array}$ & $\begin{array}{c}5.81494 \mathrm{E}+ \\
12 \\
\end{array}$ \\
\hline $\begin{array}{c}\text { SE } \\
\text { Mean }\end{array}$ & 1.72 & 0.59 & 0.46 & 293.88 & 0.53 & 0.01 & 968.92 & 0.63 & 39.26 & 0.02 & 0.44 & $\begin{array}{c}460382848 \\
9\end{array}$ \\
\hline $\begin{array}{l}\text { LCL } \\
\text { Mean }\end{array}$ & 67.98 & 17.27 & 12.95 & 1009.85 & 17.02 & 0.16 & 5451.92 & 24.50 & 152.74 & 0.40 & 12.36 & $\begin{array}{c}223143792 \\
83\end{array}$ \\
\hline $\begin{array}{l}\text { UCL } \\
\text { Mean }\end{array}$ & 68.19 & 17.34 & 13.01 & 1046.74 & 17.09 & 0.16 & 5573.56 & 24.58 & 157.67 & 0.41 & 12.42 & $\begin{array}{c}234725878 \\
51\end{array}$ \\
\hline Variance & 748.58 & 87.74 & 53.51 & $\begin{array}{c}21937344 \\
.43\end{array}$ & 72.27 & 0.03 & $\begin{array}{c}23845858 \\
3.59\end{array}$ & $\begin{array}{c}100.2 \\
4\end{array}$ & $\begin{array}{c}391598 . \\
54\end{array}$ & 0.08 & 49.46 & $\begin{array}{c}5.38359 \mathrm{E}+ \\
21\end{array}$ \\
\hline Stdev & 27.36 & 9.37 & 7.32 & 4683.73 & 8.50 & 0.19 & 15442.10 & 10.01 & 625.78 & 0.29 & 7.03 & $\begin{array}{c}733729523 \\
52\end{array}$ \\
\hline $\begin{array}{c}\text { Skewnes } \\
\text { s }\end{array}$ & -1.10 & 0.51 & 0.83 & 5.32 & 0.66 & 1.51 & 4.83 & 0.26 & 4.24 & -0.18 & 0.49 & 5.511096 \\
\hline Kurtosis & 0.03 & 0.24 & 1.26 & 28.40 & 0.79 & 1.95 & 23.33 & 0.56 & 17.29 & -1.16 & 0.40 & 31.208208 \\
\hline
\end{tabular}




\subsection{Efficiency Computation}

Efficiency for Technical (CRS), Pure Technical efficiency (BCC) and Scale efficiency (CRS/BCC) were computed using the Benchmark package ( $\mathrm{R}$ package for computing DEA Efficiency). The following models describe results from our research.

BCC Model is the Variable Return to Scale (VRS) DEA model.

CCR Model is the Constant Return to Scale Model (CRS) DEA model.

SE is the Scale Efficiency model calculated by dividing CCR by BCC.

FBCCModel is a fuzzified GA BCC model

FCCRModel is a fuzzified GA CCR model

FSE is fuzzified Scale Efficiency calculated by dividing FCCRModel by FBCCModel.

Decision Criteria

This research evaluates the validity of this research using
Spearsons rho statistic. The hypothesis for validation of models are:

Ho: rho $=0$ i.e the rank correlation of model 1 and Model 2 are not statistical different.

HA: rho is not equal to 0 : i.e the rank correlation of model 1 and Model 2 are statistical different.

Also, the following efficiency ranges will be used to describe the degree of efficiency of each model under study.

Table 4. Sensitivity Analysis for efficiency score range
\begin{tabular}{|l|l|}
\hline Eff range & Decision \\
\hline $\mathrm{E}<=0.2$ & Inefficient \\
\hline $0.1<=\mathrm{E}<0.5$ & Partially Inefficient \\
\hline $0.5<=\mathrm{E}<0.1$ & Partially Efficient \\
\hline $\mathrm{E}==1$ & Perfectly Efficiently \\
\hline
\end{tabular}

\subsubsection{Efficient scores with Alpha cut $<0.05$}

Table 5. Efficient distributions at Alpha cut $<0.05$

\begin{tabular}{|c|c|c|c|c|c|c|c|c|c|c|c|c|}
\hline & \multicolumn{12}{|c|}{$\alpha$-cut $=0.01$ Conf. Int. } \\
\hline & \multicolumn{2}{|c|}{ BCCModel } & \multicolumn{2}{|c|}{ CCRModel } & \multicolumn{2}{|c|}{ SE } & \multicolumn{2}{|c|}{ FBCCModel } & \multicolumn{2}{|c|}{ FCCRModel } & \multicolumn{2}{|c|}{ FSE } \\
\hline $\begin{array}{l}\text { Eff } \\
\text { range }\end{array}$ & Freq. & $\%$ & Freq. & $\%$ & Freq. & $\%$ & Freq. & $\%$ & Freq. & $\%$ & Freq. & $\%$ \\
\hline $\mathrm{E}=0$ & 0 & 0.00 & 0 & 0.00 & 0 & 0.00 & 0 & 0.00 & 0 & 0.00 & 0 & 0.00 \\
\hline $\begin{array}{r}0.1<= \\
\mathrm{E}<0.5\end{array}$ & 0 & 0.00 & 132 & 52.38 & 127 & 50.40 & 0 & 0.00 & 132 & 52.38 & 128 & 50.79 \\
\hline $\begin{array}{c}0.5<= \\
E<1\end{array}$ & 59 & 23.23 & 58 & 23.02 & 63 & 25.00 & 44 & 17.32 & 58 & 23.02 & 62 & 24.60 \\
\hline $\mathrm{E}==1$ & 195 & 76.77 & 62 & 24.60 & 62 & 24.60 & 210 & 82.68 & 62 & 24.60 & 62 & 24.60 \\
\hline Total & 254 & 100 & 252 & 100.00 & 252 & 100.00 & 254 & 100.00 & 252 & 100.00 & 252 & 100.00 \\
\hline $\begin{array}{l}\text { mean } \\
\text { eff }\end{array}$ & 0.97 & & 0.56 & & 0.57 & & 0.96 & & 0.69 & & 0.71 & \\
\hline min eff & 0.69 & & 0.04 & & 0.05 & & 0.64 & & 0.07 & & 0.08 & \\
\hline $\begin{array}{l}\max \\
\text { eff }\end{array}$ & 1 & & 1 & & 1 & & 1 & & 1 & & 1 & \\
\hline
\end{tabular}

Table 6. Validation of Models at Alpha cut $<0.05$

\begin{tabular}{|l|l|l|l|l|l|l|c|}
\hline Validation of Models & Data Name & Statistics & Conf. Int. & Ho & Ha & rho-Estimate & P-value \\
\hline Model 1:DEA & bcc\$eff and fbcc\$eff & 1766895.78 & 0.01 & 0.00 & less & 0.35 & 1.00 \\
\hline Model 2:FBootDEA & ccr\$eff and fccr\$eff & 777.30 & 0.01 & 0.00 & less & 1.00 & 1.00 \\
\hline
\end{tabular}

At 0.01 Significant level, the critical value is 2.326. Both model 1 and model 2 rho value was less than the critical value. Therefore, the null hypothesis is accepted while the alternate hypothesis is rejected. We conclude therefore that the both model are not statistically different.

Table 7. Perfectly Efficient DMU by Years at alpha cut $<0.05$

\begin{tabular}{|l|l|l|}
\hline & \multicolumn{1}{|c|}{ SE } & \multicolumn{1}{|c|}{ FSE } \\
\hline 1999 & Gambia, Liberia, Niger & Gambia, Liberia, Niger \\
\hline 2000 & Guinea, Guinea-Bissau, Liberia, Nigeria & Guinea, Guinea-Bissau, Liberia, Nigeria \\
\hline
\end{tabular}




\begin{tabular}{|l|l|l|}
\hline 2001 & Guinea, Guinea-Bissau, Liberia, Niger & Guinea, Guinea-Bissau, Liberia, Niger \\
\hline 2002 & Guinea, Guinea-Bissau, Liberia, Niger & Guinea, Guinea-Bissau, Liberia, Niger \\
\hline 2003 & Guinea, Guinea-Bissau, Liberia, Niger & Guinea, Guinea-Bissau, Liberia, Niger \\
\hline 2004 & Guinea, Guinea-Bissau, Liberia & Guinea, Guinea-Bissau, Liberia \\
\hline 2005 & Guinea, Guinea-Bissau & Guinea, Guinea-Bissau \\
\hline 2006 & Guinea-Bissau & Guinea-Bissau \\
\hline 2007 & Guinea, Guinea-Bissau & Guinea, Guinea-Bissau \\
\hline 2008 & Burkina Faso, Guinea, Guinea-Bissau & Burkina Faso, Guinea, Guinea-Bissau \\
\hline 2009 & Guinea, Guinea-Bissau & Guinea, Guinea-Bissau \\
\hline 2010 & Liberia, Nigeria & Liberia, Nigeria \\
\hline 2011 & Liberia, Nigeria & Liberia, Nigeria \\
\hline 2012 & Guinea-Bissau, Liberia, Nigeria & Guinea-Bissau, Liberia, Nigeria \\
\hline 2013 & Liberia, Nigeria, Sierra Leone & Liberia, Nigeria, Sierra Leone \\
\hline 2014 & $\begin{array}{l}\text { Benin, Cameroon, Guinea, Guinea-Bissau, Liberia, Mali, } \\
\text { Niger, Nigeria, Sierra Leone }\end{array}$ & $\begin{array}{l}\text { Benin, Cameroon, Guinea, Guinea-Bissau, Liberia, Mali, } \\
\text { Niger, Nigeria, Sierra Leone }\end{array}$ \\
\hline 2015 & $\begin{array}{l}\text { Benin, Cameroon, Gambia, Guinea, Guinea-Bissau, } \\
\text { Liberia, Mali, Niger, Nigeria, Senegal, Togo }\end{array}$ & $\begin{array}{l}\text { Benin, Cameroon, Guinea, Guinea-Bissau, Liberia, Mali, } \\
\text { Niger, Nigeria, Senegal, Togo }\end{array}$ \\
\hline
\end{tabular}

Table 8. Inefficient DMU by Years at alpha cut $<0.05$

\begin{tabular}{|r|l|l|}
\hline & SE & \multicolumn{1}{|c|}{ FSE } \\
\hline 2011 & Gambia & Gambia \\
\hline 2012 & Togo & Togo \\
\hline
\end{tabular}

\subsubsection{Efficient scores with Alpha cut=0.05}

Table 9. Efficient score at Alpha cut=0.05

\begin{tabular}{|c|c|c|c|c|c|c|c|c|c|c|c|c|}
\hline & \multicolumn{12}{|c|}{$\alpha$-cut $=0.05$ Conf. Int. } \\
\hline & \multicolumn{2}{|c|}{ BCCModel } & \multicolumn{2}{|c|}{ CCRModel } & \multicolumn{2}{|c|}{ SE } & \multicolumn{2}{|c|}{ FBCCModel } & \multicolumn{2}{|c|}{ FCCRModel } & \multicolumn{2}{|c|}{ FSE } \\
\hline Eff range & Freq. & $\%$ & Freq. & $\%$ & Freq. & $\%$ & Freq. & $\%$ & Freq. & $\%$ & Freq. & $\%$ \\
\hline $\mathrm{E}=0$ & 0 & 0.00 & 0 & 0.00 & 0 & 0.00 & 0 & 0.00 & 0 & 0.00 & 0 & 0.00 \\
\hline $0.1<=\mathrm{E}<0.5$ & 0 & 0.00 & 132 & 52.38 & 127 & 50.40 & 0 & 0.00 & 132 & 52.38 & 125 & 49.60 \\
\hline $0.5<=\mathrm{E}<1$ & 59 & 23.23 & 58 & 23.02 & 63 & 25.00 & 44 & 17.32 & 58 & 23.02 & 65 & 25.79 \\
\hline $\mathrm{E}==1$ & 195 & 76.77 & 62 & 24.60 & 62 & 24.60 & 210 & 82.68 & 62 & 24.60 & 62 & 24.60 \\
\hline Total & 254 & 100 & 252 & 100.00 & 252 & 100.00 & 254 & 100.00 & 252 & 100.00 & 252 & 100.00 \\
\hline mean eff & 0.97 & & 0.56 & & 0.57 & & 0.98 & & 0.56 & & 0.57 & \\
\hline min eff & 0.69 & & 0.04 & & 0.05 & & 0.64 & & 0.05 & & 0.05 & \\
\hline max eff & 1 & & 1 & & 1 & & 1 & & 1 & & 1 & \\
\hline
\end{tabular}

Table 10. Validation of Model at Alpha cut $=0.05$

\begin{tabular}{|l|l|l|l|l|l|l|l|}
\hline $\begin{array}{l}\text { Validation of } \\
\text { Model }\end{array}$ & Data Name & Statistics & $\begin{array}{l}\text { Conf. } \\
\text { Int. }\end{array}$ & Ho & Ha & rho-Estimate & P-value \\
\hline Model 1:DEA & bcc\$eff and fbcc\$eff & 1785540.87 & 0.05 & 0.00 & less & 0.35 & 1.00 \\
\hline $\begin{array}{l}\text { Model } \\
\text { 2:FBootDEA }\end{array}$ & ccr\$eff and fccr\$eff & 3332.45 & 0.05 & 0.00 & less & 1.00 & 1.00 \\
\hline
\end{tabular}

At 0.01 Significant level, the critical value is 1.645 . Both model 1 and model 2 rho value was less than the critical value. Therefore, the null hypothesis is accepted while the alternate hypothesis is rejected. 
Table 11. Perfectly Efficient DMU by Years at alpha cut $=0.05$

\begin{tabular}{|c|l|l|}
\hline Year & \multicolumn{1}{|c|}{ SE } & \multicolumn{1}{|c|}{ FSE } \\
\hline 1999 & Gambia, Liberia, Niger & Gambia, Liberia, Niger \\
\hline 2000 & Guinea, Guinea-Bissau, Liberia, Nigeria & Guinea, Guinea-Bissau, Liberia, Nigeria \\
\hline 2001 & Guinea, Guinea-Bissau, Liberia, Niger & Guinea, Guinea-Bissau, Liberia, Niger \\
\hline 2002 & Guinea, Guinea-Bissau, Liberia, Niger & Guinea, Guinea-Bissau, Liberia, Niger \\
\hline 2003 & Guinea, Guinea-Bissau, Liberia, Niger & Guinea, Guinea-Bissau, Liberia, Niger \\
\hline 2004 & Guinea, Guinea-Bissau, Liberia & Guinea, Guinea-Bissau, Liberia \\
\hline 2005 & Guinea, Guinea-Bissau & Guinea, Guinea-Bissau \\
\hline 2006 & Guinea-Bissau & Guinea-Bissau \\
\hline 2007 & Guinea, Guinea-Bissau & Guinea, Guinea-Bissau \\
\hline 2008 & Burkina Faso, Guinea, Guinea-Bissau & Burkina Faso, Guinea, Guinea-Bissau \\
\hline 2009 & Guinea, Guinea-Bissau & Guinea, Guinea-Bissau \\
\hline 2010 & Liberia, Nigeria & Liberia, Nigeria \\
\hline 2011 & Liberia, Nigeria & Liberia, Nigeria \\
\hline 2012 & Guinea-Bissau, Liberia, Nigeria & Guinea-Bissau, Liberia, Nigeria \\
\hline 2013 & Liberia, Nigeria, Sierra Leone & Liberia, Nigeria, Sierra Leone \\
\hline 2014 & $\begin{array}{l}\text { Benin, Cameroon, Guinea, Guinea-Bissau, Liberia, Mali, } \\
\text { Niger, Nigeria, Sierra Leone }\end{array}$ & $\begin{array}{l}\text { Benin, Cameroon, Guinea, Guinea-Bissau, Liberia, Mali, } \\
\text { Niger, Nigeria, Sierra Leone }\end{array}$ \\
\hline 2015 & $\begin{array}{l}\text { Benin, Cameroon, Gambia, Guinea, Guinea-Bissau, } \\
\text { Liberia, Mali, Niger, Nigeria, Senegal, Togo }\end{array}$ & $\begin{array}{l}\text { Benin,Cameroon,Gambia,Guinea,Guinea- } \\
\text { Bissau,Liberia,Mali,Niger,Nigeria,Senegal, Togo }\end{array}$ \\
\hline
\end{tabular}

Table 12: Inefficient DMU by Years at alpha cut $=0.05$

\subsubsection{Efficient scores with Alpha cut $>0.05$}

\begin{tabular}{|l|l|l|}
\hline & SE & FSE \\
\hline 2011 & Gambia & Gambia \\
\hline 2012 & Togo & Togo \\
\hline
\end{tabular}

\section{Table 13: Efficient score at Alpha cut $>0.05$}

\begin{tabular}{|c|c|c|c|c|c|c|c|c|c|c|c|c|}
\hline & \multicolumn{2}{|c|}{ BCCModel } & \multicolumn{2}{|c|}{ CCRModel } & \multicolumn{2}{|c|}{ SE } & \multicolumn{2}{|c|}{ FBCCModel } & \multicolumn{2}{|c|}{ FCCRModel } & \multicolumn{2}{|c|}{ FSE } \\
\hline Eff range & Freq. & $\%$ & Freq. & $\%$ & Freq. & $\%$ & Freq. & $\%$ & Freq. & $\%$ & Freq. & $\%$ \\
\hline $\mathrm{E}=0$ & 0 & 0.00 & 0 & 0.00 & 0 & 0.00 & 0 & 0.00 & 0 & 0.00 & 0 & 0.00 \\
\hline $0.1<=\mathrm{E}<0.5$ & 0 & 0.00 & 132 & 52.38 & 127 & 50.40 & 0 & 0.00 & 71 & 28.06 & 58 & 22.92 \\
\hline $0.5<=\mathrm{E}<1$ & 59 & 23.23 & 58 & 23.02 & 63 & 25.00 & 89 & 35.04 & 108 & 42.69 & 121 & 47.83 \\
\hline $\mathrm{E}==1$ & 195 & 76.77 & 62 & 24.60 & 62 & 24.60 & 165 & 64.96 & 74 & 29.25 & 74 & 29.25 \\
\hline Total & 254 & 100 & 252 & 100.00 & 252 & 100.00 & 254 & 100.00 & 253 & 100.00 & 253 & 100.00 \\
\hline mean eff & 0.97 & & 0.56 & & 0.57 & & 0.96 & & 0.69 & & 0.71 & \\
\hline min eff & 0.69 & & 0.04 & & 0.05 & & 0.64 & & 0.07 & & 0.08 & \\
\hline max eff & 1 & & 1 & & 1 & & 1 & & 1 & & 1 & \\
\hline
\end{tabular}

Table 14: Validation of Model at Alpha cut $>0.05$

\begin{tabular}{|l|l|l|l|l|l|l|l|}
\hline & Data Name & Statistics & Conf. Int. & Ho & Ha & rho- & P-value \\
\hline Model 1:DEA & bcc\$eff and fbcc\$eff & 1155094.33 & 0.1 & 0.00 & less & 0.58 & 1.00 \\
\hline Model 2:FBootDEA & ccr\$eff and fccr\$eff & 607023.07 & 0.1 & 0.00 & less & 0.78 & 1.00 \\
\hline
\end{tabular}

At 0.01 Significant level, the critical value is 1.282. Both value. Therefore, the null hypothesis is accepted while the model 1 and model 2 rho values was less than the critical alternate is rejected. 
Table 15:Perfectly Efficient DMU by Years at alpha cut $>0.05$

\begin{tabular}{|c|c|c|}
\hline & SE & FSE \\
\hline 1999 & Gambia, Liberia, Niger & Cameroon, Gambia, Liberia, Niger, \\
\hline 2000 & Guinea, Guinea-Bissau, Liberia, Nigeria & Gambia, Guinea, Guinea-Bissau, Liberia, Mali, Niger, Nigeria \\
\hline 2001 & Guinea, Guinea-Bissau, Liberia, Niger & Guinea, Guinea-Bissau, Liberia, Niger, Sierra Leone \\
\hline 2002 & Guinea, Guinea-Bissau, Liberia, Niger, & Guinea, Guinea-Bissau, Liberia, Niger \\
\hline 2003 & Guinea, Guinea-Bissau, Liberia, Niger & Guinea, Guinea-Bissau, Liberia, Niger, Togo \\
\hline 2004 & Guinea, Guinea-Bissau, Liberia & Guinea, Guinea-Bissau, Liberia, \\
\hline 2005 & Guinea, Guinea-Bissau, & Guinea, Guinea-Bissau, Liberia, \\
\hline 2006 & Guinea-Bissau, & Benin, Guinea-Bissau, \\
\hline 2007 & Guinea, Guinea-Bissau, & Guinea, Guinea-Bissau, \\
\hline 2008 & Burkina Faso, Guinea, Guinea-Bissau & Burkina Faso, Guinea, Guinea-Bissau, Liberia, \\
\hline 2009 & Guinea, Guinea-Bissau, & Guinea, Guinea-Bissau, Nigeria, \\
\hline 2010 & Liberia, Nigeria & Liberia, Nigeria, \\
\hline 2011 & Liberia, Nigeria & Liberia, Nigeria, \\
\hline 2012 & Guinea-Bissau, Liberia, Nigeria & Guinea-Bissau, Liberia, Nigeria, \\
\hline 2013 & Liberia, Nigeria, Sierra Leone & Liberia, Nigeria, Sierra Leone, \\
\hline 2014 & $\begin{array}{l}\text { Benin, Cameroon, Guinea, Guinea-Bissau, } \\
\text { Liberia,Mali, Niger, Nigeria, Sierra Leone }\end{array}$ & $\begin{array}{l}\text { Benin, Cameroon, Guinea, Guinea-Bissau, Liberia, Mali, Niger, } \\
\text { Nigeria, Sierra Leone, }\end{array}$ \\
\hline 2015 & $\begin{array}{l}\text { Benin, Cameroon, Gambia, Guinea, Guinea- } \\
\text { Bissau, Liberia, Mali, Niger, Nigeria, Senegal, }\end{array}$ & $\begin{array}{l}\text { Benin, Burkina Faso, Cameroon, Gambia,Guinea, Guinea-Bissau, } \\
\text { Liberia, Mali, Niger, Nigeria, Senegal, Togo }\end{array}$ \\
\hline
\end{tabular}

Table 16: Perfectly Efficient DMU by Years at alpha cut $>0.05$

\begin{tabular}{|c|l|c|}
\hline & \multicolumn{1}{|c|}{ SE } & FSE \\
\hline 2002 & & Togo \\
\hline 2011 & Gambia & Gambia \\
\hline 2012 & Togo & \\
\hline
\end{tabular}

\subsection{Interpretation of Results}

At $\alpha$-cut less than 0.05 Significant level (table 5),

For Perfectly Efficient score (E=1): 76.77\%(195 DMUs) under the BCC model, 24.41\%(62 DMUs) under the CCR Model and SE Model, 82.68\%(210 DMUs) under FBCC model, 24.41(62 DMUs) under FCCRModel and FSE model had efficiency score equal to 1 , an indication that they were perfectly efficient and no waste of economic resources.

For Perfectly Inefficient score $(\mathbf{0 . 1}<=\mathbf{E}<\mathbf{0 . 5})$ : 132 DMUs(52.38\%) under CCRModel, 127 DMUs(50.40\%) under the SE model, 132 DMUs $(52.38 \%)$ under the FCCR model and 128 DMUs(50.79\%) under FSE model were perfectly inefficient.

For Partially Efficient score (0.5<=E $<\mathbf{1}): 59(23.23 \%)$ under the BCC model, 58 DMUs(23.02\%) under CCRModel, 63 DMUs(25.00\%) under the SE model, 44 DMUs(17.32\%) under the FBCC model, 58 DMUs(23.02\%) under FCCR model and 62 DMUs(24.60\%) under the FSE model were perfectly inefficient.

For Inefficient score $(\mathbf{E}<=\mathbf{0})$ : No DMU had efficiency score less than or equal to zero. Two DMUs were technically infeasible under CCR, SE, FCCR and FSE model.See appendix A1 for list of countries under these range and efficiency classification by year. At $\alpha$-cut equals to 0.05 Significant level (table 9),
For Perfectly Efficient score (E=1): 195(76.77\%), $62(24.60 \%), 62(24.60 \%), \quad 210(82.68 \%), 62(24.60 \%)$ and $62(24.60 \%)$ were perfectly efficiency under BCC model, CCR Model, SE Model, FBCC model FCCRModel and FSE respectively.

For Perfectly Inefficient score $(\mathbf{0 . 1}<=\mathbf{E}<\mathbf{0 . 5})$ : $132(52.38 \%)$, $127(50.40 \%), 132(52.38 \%), 125(49.60 \%)$ were perfectly inefficiency under CCR Model, SE Model, FCCRModel and FSE respectively.

For Partially Efficient score (0.5<=E $<\mathbf{1})$ : $59(23.23 \%)$ under the BCC model, 58 DMUs(23.02\%) under CCRModel, 63 DMUs $(25.00 \%)$ under the SE model, 44 DMUs(17.32\%) under the FBCC model, 58 DMUs(23.02\%) under FCCR model and 65 DMUs $(25.79 \%)$ under the FSE model were Partially efficient.

For Inefficient score $(\mathbf{E}<=\mathbf{0})$ : No DMU had efficiency score less than or equal to zero.Two DMUs were technically infeasible under CCR, SE, FCCR and FSE model. See appendix A2 for list of countries under these range and efficiency classification by year. At $\alpha$-cut greater than 0.05 Significant level (table 11),

For Perfectly Efficient score (E=1): 195(76.77\%), 62(24.60\%), 62(24.60\%), $165(64.96 \%), 74(29.25 \%)$ and 74 $(29.25 \%)$ were perfectly efficiency under BCC model, CCR Model, SE Model, FBCC model FCCRModel and FSE respectively. 
For Perfectly Inefficient score (0.1<=E $<0.5)$ : 132(52.38\%), $127(50.40 \%), \quad 71(28.06 \%), 58(22.92 \%)$ were perfectly inefficiency under CCR Model, SE Model, FCCR Model and FSE Model respectively.

For Partially Efficient score (0.5<=E $<\mathbf{1})$ : $59(23.23 \%)$ under the BCC model, 58 DMUs(23.02\%) under CCRModel, 63 DMUs $(25.00 \%)$ under the SE model, 89 DMUs(35.04\%) under the FBCC model, 108 DMUs(42.69\%) under FCCR model and 121 DMUs(47.83\%) under the FSE model were Partially efficient.

For Inefficient score $(\mathbf{E}<=\mathbf{0})$ : No DMU had efficiency score less than or equal to zero.

Two DMUs were technically infeasible under CCR, SE, FCCR and FSE model.

See appendix A3 for list of countries under these alpha cut $>$ 0.05 and efficiency classification by year.

\section{CONCLUSION}

Soft computing (GA and Fuzzy) and non-parametric DEA method was used to offer a hybrid model that was used to select best subset of determinants of economic growth and measure countries efficiency. It was also used to identify countries that were inefficient during the period under study. This study provides an in-depth sensitivity analysis of efficiency measurement where the economy or country growth is a function of the financial development of the financial sector. This study provides a flexible template that could be used to predict future efficiency of a country if certain estimates/values are used for selected subset variables. Increasing the diversity of the model will simultaneously increase the sensitivity of the model in determining variables that better predict the efficiency of a country under any condition or government policies since these are catalyst that engineer the financial development of the financial sector which in turn accelerate GDP that will possibly reflect in the economic growths.

\section{REFERENCES}

[1] Abu, N., 2009. Does stock market development raise economic growth? Evidence from Nigeria. Journal of Banking and Finance, 1 (1), 15-26.

[2] Abubakar, A.B. and Waziri, M.Y., 2016. A matrix-free approach for solving systems of nonlinear equations. Journal of Modern Methods in Numerical Mathematics, 7(1), pp.1-9.

[3] Adekunle, O., Ganiyu, S., \& Adedipe, O., 2013. Impact of financial sector development on the Nigerian economic growth. American Journal of Business and Management , 2 (4), 347-356.

[4] Adua, G., Marbuah, G., \& Mensah, J., 2013. Financial development and economic growth in Ghana: Does the measure of financial development matter? Review of. Review of Development Finance , 3, 192-203.

[5] Afzal, M., 2007. The Impact of Globalisation on Economic Growth of Pakistan. The Pakistan Development Review , 723-734.

[6] Ahmed, S. and Mortaza, M.G., 2010. Inflation and economic growth in Bangladesh: 1981-2005 (No. id: 3033).

[7] Ajide, K., 2011. Determinants of Economic Growth in Nigeria. CBN Journal of Applied Statistics , 5 (2), 147-
170.

[8] Akinboye, S., 2008. Globalization and the challenge for Nigeriae's Development in 21stcentury. University of Lagos, Lagos.

[9] Akingunola, R., Olusegun, A., Oluwaseyi, B., \& Olusoji, G., 2013. The effect of the financial liberalisation on economic growth. International Journal of Academic Research in Economics and Management Sciences. , 2 (1), 123-155.

[10] Al-fali, M., 2006. The Nigerian capital market and socioeconomic Development”. Paper presented at the 4th distinguished public lecture, university of Benin, Faculty of social science, Benin City.

[11] Aliheidari, T., \& Khademi, H., 2014. Adaptive DEA for clustering of credit clients. Journal of Applied Research on Industrial Engineering , 1 (1), 35-49.

[12] Al-Slamy, N. M., 2008. E-Commerce security. International Journal of Computer Science and Network Security , 8 (5), 340-344.

[13] Andros, G. and Sugata, G., 2006. The Impact of Government Expenditure on Growth: Empirical Evidence from a Heterogeneous Panel. Economics and Finance, Brunel University, Uxbridge, Middlesex.

[14] Ardic, O., \& Dama, H., 2006. Financial sector deepening and economic growth: Evidence from Turkey, 1-25. Bogazici University, Department of Economics. Bogazici: Bogazici University.

[15] Artelaris, P., Arvanitidis, P., \& Petrakos, G., 2007. Theoretical and methodological study on dynamic growth regions and factors explaining their growth performance. Paper presented at the 2nd Workshop of DYNREG in Athens, 9-10 March. Dynamic Regions in a Knowledge- Driven Global Economy Lessons and Policy I. DYNREG.

[16] Aurangzeb, A.Z., 2006. Exports, productivity and economic growth in Pakistan: a time series analysis. Lahore Journal of Economics, 11(1), pp.1-18.

[17] Awan, M.Z., Khan, B. and uz Zaman, K., 2011. Economic determinants of foreign direct investment (FDI) in commodity producing sector: A case study of Pakistan. African Journal of Business Management, 5(2), p.537.

[18] Aye, G., 2015. Causality between financial deepening and economic growth in Nigeria: Evidence from a bootstrap rolling window approach. Journal of Economics,Business and Management , 3 (8), 795-801.

[19] Bakay, A., 2014. Granger causality between financial deepening and international trade: Evidence from regional panel data. Eurasian Journal of Business and Economics. , 7 (14), 91-107.

[20] Banker, R., Charnes, A., \& Cooper, W. (1984). Some models for estimating technical and scale inefficiencies in data envelopment analysis. Management Science , 108-1092.

[21] Bardhan, I., Bowlin, W., Cooper, W., \& Sueyoshi, T., 1996. Models and Measures for Efficiency Dominance in DEA, Part I: Additive Models and MED Measures. Journal of the Operational Research Society of Japan , 322-332. 
[22] Bogetoft, P., \& Otto, L., 2015. Benchmark and Frontier Analysis Using DEA and SFA. CRAN.

[23] Bogetoft, P., \& Otto, L., 2011. Benchmarking with DEA, SFA, and R. London: Springer Science Business Media.

[24] Buyukozlan, G., \& Cifci, G., 2012. A combined fuzzy AHP and fuzzyTOPSIS based trategic abalysis of electronic service quality in Healthcare insustry. Expert Systems with application , 39, 2341-2354.

[25] Cadima, J., Peixoto, C. and Leal, T., 2014. Observed classroom quality in first grade: Associations with teacher, classroom, and school characteristics. European journal of psychology of education, 29(1), pp.139-158.

[26] Caporale, G., Rault, C., Sova, R., \& Sova, A., 2009. Financial Development and Economic Growth: Evidence from Ten New EU Members. Berlin: German Institute for Economic Research.

[27] Carrasco, R., Munoz-Leiva, F., \& Sanchez-Fernandez, J., 2012. A Model for the integration of e-fiancial service questionnaires with SERVQUAL sclae under fuzzy linguistic modeling. Expert Systems with Applications , $39,11535-1154$

[28] Charnes, A., Cooper, W., \& Rhodes, E., 1978. Measuring Efficiency of decsion making units. European Journal of Operational Research , 2, 429-44.

[29] Cinca, C.S. and Molinero, C.M., 2004. Selecting DEA specifications and ranking units via PCA. Journal of the Operational Research Society, 55(5), pp.521-528.

[30] Cook, W. D., \& Zhu, J., 2006. Rank order data in DEA: A general framework. European Journal of Operational Research , 174 (2), 1021-1038.

[31] Dehghan, M., Hashemi, B., \& Ghatee, M., 2006. Computational methods for solving fully fuzzy linear systems. Applied Mathematics and Computations , 179, 328-343.

[32] Donwa, P., \& Odio, J., 2010. An Empirical Analysis of the Impact of Nigerian Capital Market on her socioeconomic development. Journal of Social Science , 24, $137-138$.

[33] Emrouznejad, A. and Anouze, A.L., 2010. A note on the modeling the efficiency of top Arab banks. Expert Systems with Applications, 36(3), pp.5741-5744.

[34] Ewan, S., Esang, A., \& Bassey, J. U., 2009. Appraisal of Capital market efficiency on economic growth in Nigeria. International journal of Business and management.. Firm, 219-225.

[35] Farrell, M.J., 1957. The measurement of productive efficiency. Journal of the Royal Statistical Society: Series A (General), 120(3), pp.253-281.

[36] Gaburro, G., \& O’Boyle, E., 2003. Norms for evaluating globalization. International Journal of Social Economics , $30(1 / 2), 95-118$.

[37] Greenberg, A., 2005. ICTs for Poverty Alleviation, Basic tool and Enabling Sector, ICT for development Secretariat. SIDA .

[38] Grinstein, G., Hoffman, P., \& Pickett, R., 2002. Benchmark Development for the Evaluation of Visualization for Data Mining. In Fayyad U., G. Grinstein and A. Wierse, Information Visualization in
Data Mining and Knowledge Discovery.

[39] Gupta, R., \& Goel, D., 2014. Indian Capital Market: An overview. International Journal of Emerging Research Management and Technology , 3 (5), 55-63.

[40] Hanen, H., Emrouznejad, A., \& Ouertani, M., 2013. Technical fficincy detereminants within a Dual Banking System:a DEA bootstrap approach. Brimingham: Aston University.

[41] Houssine, T., 2013. A Fuzzy Data Envelopment Analysis model to evaluate the Tunisian banks efficiency. International Journal of Scientific \& Engineering Research , 4 (9), 1924-1929.

[42] Ilaboya, O., \& Ibrahim, S. 2004. Impact of stock market performance on the level of economic activities; evidence from Nigerian stock market. Nigerian journal of Business administration. , 6 (1), 53-82.

[43] Jenkins, L. and Anderson, M., 2003. A multivariate statistical approach to reducing the number of variables in data envelopment analysis. European Journal of Operational Research, 147(1), pp.51-61.

[44] Johannes, T., Njong, A., \& Cletus, N., 2011. The financial system can play an important role in Cameroon, 1970-2005. Journal of Economics and International Finance , 3 (6), 367-375.

[45] Kargbo, A., Ding, Y., \& Kabia, B., 2015. Situational analysis of financial deepening in low, middle and high income economies international. Journal of Business Management and Economic Research (IJBMER). , 6 (2), 143-157.

[46] Kaufmann, A., \& Gupta, M., 1985. Introduction to Fuzzy Arithmetic Theory and Applications. New York: Van Nostrand Reinhold.

[47] Kazemi, M., \& Alimi, A., 2014. A fully fuzzy approach to data envelopment analysis. Journal of Mathematics and Computer Sciences , 11, 238-245.

[48] Kira, A.,2013. The Factors Affecting Gross Domestic Product (GDP) in Developing Countries: The Case of Tanzania. European Journal of Business and Management , 148-158.

[49] Kolapo, F., \& Adaramola, A., 2012. The Impact of the Nigerian Capital Market on Economic Growth. International Journal of Development Societies. , 1 (1), $17-26$.

[50] Lin, .D. (2010). Fuzzy Application in service quality analysis: An empirical Study. Expert Systems with Application , 37 (1), 517-526.

[51] Madhanagopal, R. and Chandrasekaran, R., 2014. Selecting appropriate variables for DEA using genetic algorithm (GA) search procedure. International Journal of Data Envelopment Analysis and Operations Research, 1(2), pp.28-33.

[52] Mehmood, M., 2012. Effect of Different Factors on Gross Domestic Product: A Comparative Study of Pakistan and Bangladesh. Academy of Contemporary Research Journal , 1 (1), 11-22.

[53] Mhadhbi, K., 2014. Financial development and economic growth: A dynamic panel data analysis. International Journal of Econometrics and Financial Management , 2, 
49-58.

[54] Mirdala, R., 2011. Financial deepening and economic growth in the European transition economies. Technical University of Kosice, Faculty of Economics. Slovakia: MPRA Paper No. 33609.

[55] Nazir, S., Nawaz, M., \& Gilani, J., 2010. Relationship between economic growth and stock market development. African journal of business management. , 4 (16), 3473-346.

[56] Ngongang, E., 2015. Financial development and economic growth in Sub-Saharan Africa. A dynamic panel data analysis. European Journal of Sustainable Development , 4 (3), 369-378.

[57] Nguena, C., \& Abimbola, T., 2013. Financial deepening dynamics and implication for financial policy coordination in a monetary union: The case of WAEMU. African Economic Conference on Regional Integration in Africa., (pp. 1-22). Johannesburg.

[58] Nwokah, N., \& Adiele, K., 2015. The Socio-Economic Impact of Globalization in Nigeria. Journal of Economics and Sustainable Development , 6 (10), 233-246.

[59] Nzotta, S., \& Okereke, E., 2009. Financial deepening and economic development of Nigeria: An empirical investigation. African Journal of Accounting, Economics,Finance and Banking Research. , 5 (5), 52-66.

[60] Odetayo, T., \& Sajuyogbe, A., 2012. Impact of Nigerian capital market on economic growth and development. International journal of arts and commerce , 1 (5), 5-8.

[61] Oka, R., \& Samuel, S., 2010. Efficiency of the Nigerian capital Market: Implications for Investment Analysis and Performance. Transitional Corporations Review. , 2 (1), 45-48.

[62] Okafor, C., \& Arowoshegbe, A., 2011. Stimulating Economic Development through the Capital Market: The Nigerian experience. Journal of Research in International Development , 9 (2), 407-409.

[63] Oluwatosin, E., Taiwo, A., \& Yusuf, S., 2013. Empirical Analysis of the capital Market efficiency on Economic Growth and Development in Nigeria. International Journal of Academic research in Economics and Management Sciences. , 2 (6), 46-51.

[64] Olweny, T., \& Kimani, D., 2011. "Stock market performance and economic growth, empirical evidence from Kenya using causality test approach. Advances management and applied economics. , 1 (3), 153-196.

[65] Onwumere, J., Onudugo, V., \& Ibe, I., 2013. Financial structure and economic growth:Evidence from Nigeria. Global Journal of Management and Business Research Finance, 13 (5), 1-9.

[66] Pourshahabi, F., Mahmoudinia, D., \& Soderjani, E., 2011. FDI, Human Capital, Economic Freedom and Growth in OECD Countries. Research Journal of International Studies (19).

[67] Rana, R., \& Barua, S., 2015. Financial Development and Economic Growth: Evidence from a Panel Study On South Asian Countries. Asian Economic and Financial Review , 5 (10), 1159-1173.

[68] Saati, M., Memariani, A., \& Jahanshahloo, G., 2002.
Efficiency Analysis and rnaking of DMUs with fuzzy data. Fuzzy Optimization and Decision Making , 1, 255267.

[69] Sackey, F., \& Nkrumah, E., 2012. Financial sector deepening and economic growth in Ghana. Journal of Economics and Sustainable Development , 3 (8), 122139.

[70] Simar, L., \& Wilson, P., 2007. Estimation and inference in two-stage, semi-parametric models of production processes. Journal of Econometrics , 136 (1), 31-64.

[71] Simwaka, K., Ligoya, L., Kabango, G., \& Chikonda, M., 2012. Money supply and inflation in Malawi: An econometric investigation. International Journal of Applied Economics and Finance. , 6 (3), 74-88.

[72] Sivanandam, S., \& Deepa, S. (2008). Introduction to Genetic Algorithm. New York: Springer.

[73] Skale, M., \& Rabar, D. (2015). Measuring Economic growth using Deta evelopment Analysis. Amfiteatru Economic , 18 (42), 386-406.

[74] Sule, O., \& Momoh, O. (2009). The Impact of Stock Market Earnings on Nigerian per Capital Income. African Journal of Accounting, Economics, Finance and Banking Research. , 5 (5), 70-80.

[75] Tabi, A., Njong, A., \& Neba, C. (2011). Financial development and economic growth in Cameroon, 19702005. Journal of Economics and International Finance, 3 (6), 367-375.

[76] Tahmasebi, P. and Hezarkhani, A., 2012. A hybrid neural networks-fuzzy logic-genetic algorithm for grade estimation. Computers \& geosciences, 42, pp.18-27.

[77] Thanassoulis, E., 2001. Introduction to the theory and application of data envelopment analysis. Dordrecht: Kluwer Academic Publishers.

[78] Vissak, T. and Roolaht, T., 2005. The negative impact of foreign direct investment on the Estonian economy. Problems of Economic Transition, 48(2), pp.43-66

[79] Widiarto, I., \& Emrouznejad, A. (2015). Social and financial efficiency of Islamic microfinance institutions: A Data Envelopment Analysis application". SocioEconomic Planning Sciences, 50 (1), 1-17.

[80] Wong, A., \& Zhou, X. (2011). Development of Financial Market and economic Growth: Review of Hong Kong, China, The United states and the United Kingdom. International Journal of Economics and Finance. , 2 (3), 113.

[81] Zeng, W., \& Li, H. (2007). Weighted triangular approximation of fuzzy numbers,. International Journal of Approximate Reasoning , 46, 137-150.

[82] Zerafat, M., Emrouznejad, A., \& Mustafa, A. (2010). Fuzzy assessment of performance of a decision making units using DEA: A non-radial approach. Expert Systems with Application , 37, 5153-5157.

[83] Zhu, J., \& Cook, W. D. (2007). Modeling Data Irregularities and Structural Complexities in Data Envelopment Analysis. Springer. 